Received Date : 11-May-2015

Revised Date : 09-Dec-2015

Accepted Date : 10-Dec-2015

Article type : Original Article

Laza-Martínez et al. ---Fukuyoa paulensis from the Mediterranean Sea

\title{
Characterization of a Strain of Fukuyoa paulensis (Dinophyceae) from the Western Mediterranean Sea
}

\author{
Aitor Laza-Martínez ${ }^{\mathrm{a}}$, Helena David ${ }^{\mathrm{a}}$, Pilar Riobó ${ }^{\mathrm{b}}$, Irati Miguel ${ }^{\mathrm{c}}$, Emma Orive $^{\mathrm{a}}$ \\ a Department of Plant Biology and Ecology, University of The Basque Country (UPV/EHU), \\ Sarriena z/g, Leioa 48940, Basque Country, Spain
}

b Unidad Asociada de I+D+i Microalgas Nocivas IEO-CSIC, Instituto de Investigaciones Marinas, Eduardo Cabello, 6, 36208 Vigo, Spain

c Sequencing and Genotyping Unit from SGIker services of the University of The Basque Country (UPV/EHU), Sarriena z/g, Leioa 48940, Basque Country, Spain

\section{Correspondence}

A. Laza-Martínez, Dept. of Plant Biology and Ecology, University of The Basque Country (UPV/EHU), Sarriena s/n, 48940 Leioa, Basque Country, Spain

Telephone number: +34 946018415; FAX number: +34 946013500; e-mail: aitor.laza@ehu.es

\begin{abstract}
A single cell of the dinoflagellate genus Fukuyoa was isolated from the island of Formentera (Balearic Islands, west Mediterranean Sea), cultured and characterized by morphological and molecular methods and toxin analyses. This is the first report of the Gambierdiscus lineage (genera Fukuyoa and Gambierdiscus) from the western Mediterranean Sea, which is cooler than its eastern basin. Molecular analyses revealed that the Mediterranean strain belongs to $F$. paulensis, and that it bears LSU rDNA sequences identical to New Zealand, Australian and Brazilian strains. It also shared an identical sequence of the more variable ITS-rDNA with the Brazilian strain. Toxin analyses showed the presence of maitotoxin, 54-deoxyCTX1B and gambieric acid A. This is the first observation of the two latter compounds in a Fukuyoa strain. Therefore, both Gambierdiscus and Fukuyoa should be considered when as contributing to ciguatera fish poisoning. Different strains of Fukuyoa form a complex of morphologically cryptic lineages where $F$. paulensis stands as the most distantly related nominal species. The comparison of the ITS2 secondary structures revealed the absence of CBCs among strains. The study of the morphological and molecular traits depicted an unresolved taxonomic scenario impacted by the low strains sampling.

This article has been accepted for publication and undergone full peer review but has not been through the copyediting, typesetting, pagination and proofreading process, which may lead to differences between this version and the Version of Record. Please cite this article as doi: $10.1111 /$ jeu.12292-4669

This article is protected by copyright. All rights reserved.
\end{abstract}




\section{Keywords \\ Ciguatera; ciguatoxin; Balearic Islands; benthic dinoflagellates; Gambierdiscus; gambieric acid; maitotoxin}

REPORTS on the geographical distribution of the toxigenic genus Gambierdiscus R. Adachi \& Y. Fukuyo have increased in the last years (Parsons et al. 2012 and references therein). These dinoflagellates are responsible of ciguatera fish poisoning (CFP), a syndrome frequent in tropical and subtropical waters.

Although the effect of global warming on the spread of the Gambierdiscus species cannot be discounted, increased research in recent years has uncovered a distributional pattern broader than once thought. Thus, cells of Gambierdiscus spp. have been found not only in tropical and subtropical seas, but also in warm-temperate areas such as the Eastern Mediterranean Sea, North Carolina (USA), Japan, Canary Islands, Korea and south-eastern Australia (Aligizaki and Nikolaidis 2008; Litaker et al. 2009; Kuno et al. 2010; Fraga et al. 2011; Jeong et al. 2012; Nishimura et al. 2013; Kohli et al. 2014; Fraga and Rodríguez 2014). Furthermore, Gambierdiscus spp. have been found to thrive in much deeper depths (>50 m) than those generally considered for its surveillance (Tester et al. 2013) due to its observed ability to grow in very low light conditions (Kibler et al. 2012). However, although Gambierdiscus species can grow at lower temperatures than those typical of tropical and subtropical waters, the optimum for most species is higher than $25^{\circ} \mathrm{C}$ (Tester et al. 2010; Kibler et al. 2012), making its presence in temperate areas rather limited and its abundance scarce. The high abundance reported by Kohli et al. (2014) from south-eastern Australia constitutes an exception. A matter of discussion is whether this distributional pattern could be changing in parallel with the increasing seawater temperature.

In spite of being among the most relevant toxigenic microalgae, as responsible of estimated 25,000-500,000 ciguatera-intoxications per year (Parsons et al. 2012), the knowledge of its diversity has remained poorly studied until recently. After the generic description (Adachi and Fukuyo 1979), five additional species were added to the genus in the time-span of five years (Faust 1995; Holmes 1998; Chinain et al. 1999); whereas in the last five years, the number of described species has increased to a total of 14 (Litaker et al. 2009; Fraga et al. 2011; Nishimura et al. 2014; Fraga and Rodríguez 2014; Gómez et al. 2015). Furthermore, six clades that can be considered undescribed species have been uncovered in ribosomal gene phylogenies (Litaker et al. 2010; Nishimura et al. 2013; Xu et al. 2014).

The first three described species could be differentiated with respect to each other by morphology and were described taking into account these traits only (Adachi and Fukuyo 1979; Faust 1995; Holmes 1998). Subsequent species descriptions have included a molecular characterization in addition to the observed morphology and the assignation of strains to a particular species is difficult without molecular analyses (Litaker et al. 2009). The most used markers for this genus are the D1-D3 and the D8-D10 regions of the LSU rDNA and the SSU rDNA (Litaker et al. 2009; Kuno et al. 2010; Litaker et al. 2010; Fraga at al. 2011; Jeong et al. 2012; Nishimura et al. 2013). The ITS region of the rRNA (Litaker et al. 2009; Kuno et al. 2010; Nishimura et al. 2013) has also been used to infer genetic distances.

This genus contained two well differentiated morphotypes, globular and discoid or lenticular, that appeared also well differentiated phylogeneticaly by molecular methods (Litaker et al. 2009; Kuno et al. 2010; Litaker et al. 2010; Jeong et al. 2012; Nishimura et al. 2013; Xu et al. 2014). Recently, Gómez et al. (2015) restricted the genus Gambierdiscus sensu stricto to the lenticular forms, proposed the genus Fukuyoa F. Gómez, D. Qiu, R. M. Lopes \& S. Lin for the globular forms and described the new species F. paulensis F. Gómez, D. Qiu, R. M. Lopes \& S. Lin. Both genera form a natural group, which will be referred to as Gambierdiscus lineage hereafter. Whereas the description of Fukuyoa as a new genus for the

This article is protected by copyright. All rights reserved. 
globular Gambierdiscus species is well supported, the species delimitations within this group has been controversial and remain challenging (Nishimura et al. 2013; Rhodes et al. 2014; Murray et al. 2014).

In this study we contribute to the knowledge of this newly erected genus with the characterization of a Fukuyoa strain isolated from the western Mediterranean Sea; a warmtemperate area without previous records of the Gambierdiscus lineage. The strain has been analyzed for morphology, molecular data and toxin composition. Its affinity to the three described Fukuyoa species, F. yasumotoi, F. ruetzleri and F. paulensis, has also been discussed.

\section{MATERIALS AND METHODS}

\section{Strain isolation and culture growth}

Strain Dn35EHU was isolated from the northern Formentera Island (Fig. S1; 38 $44^{\prime}$ N, $1^{\circ}$ 24' E, Western Mediterranean Sea) from a sample taken in July 2011. Diverse macroalgae (Corallina sp., Padina sp., turf algae) were detached and collected from a sallow $(<1.5 \mathrm{~m}$ depth) area until filling a $300 \mathrm{ml}$ bottle. The bottle was shaken and the supernatant containing the detached particles was stored for its observation under the microscope. For culturing, the culture medium f/4 (Guillard and Ryther 1962), modified by adding selenium (0.006 mM $\mathrm{Na}_{2} \mathrm{SeO}_{3}$, final concentration), at a salinity of 35 was employed. Single cells were captured with a microcapillary under a Nikon Eclipse T2000-UT inverted microscope. Cells were inoculated in a 24 multiwell culture plate with $1 \mathrm{ml}$ of medium. Clonal cells that grew successfully after a month were transferred to a $25 \mathrm{~cm}^{2}$ NunclonTM culture flask (Thermo Fisher Scientific, Roskilde, Denmarc) containing $10 \mathrm{ml}$ of culture medium for maintenance. Cultures were maintained at $25^{\circ} \mathrm{C}$ and an irradiance of $50-100 \mu \mathrm{mol} \mathrm{m} \mathrm{m}^{-2} \mathrm{~s}^{-1}$ in a $12: 12 \mathrm{~h}$ light : dark regime.

\section{Morphology}

For light microscopy (LM), live or calcofluor stained cells were either observed with a Leica ${ }^{\mathrm{TM}}$ DMRB (Leica Microsystems GmbH, Wetzlar, Germany) or with a Olympus Fluoview FV500 (Olympus Optical Co. Europa, Hamburg, Germany) fluorescence confocal microscope. For images processing and measurements the software ImageJ was used.

For scanning electron microscopy (SEM) preparation, cultured cells were fixed with formaldehyde (4\% final concentration) and collected on Isopore polycarbonate membrane filters (Millipore TMTP; $5.0 \mu \mathrm{m}$ pore size; Merck-Millipore Corp., Billerica, Massachusetts USA). Filters were then rinsed twice with distilled water and dehydrated through a series of ethanol solutions $(15 \%, 30 \%, 50 \%, 70 \%, 90 \%, 95 \%$ and three times with 100\%, 10 minutes each). Filters were rinsed twice in hexamethyldisilazane (Sigma-Aldrich) for 5 min before drying. Dried filters were mounted on stubs (Agar Scientific Ltd., Essex, UK), coated with chromium and observed in a Hitachi S-4800 SEM (Hitachi Ltd., Tokyo, Japan).

Cells length was measured as the antero-posterioir axis, depth as the dorso-ventral axis and width as the transdiametral axis. For plates nomenclature the system used by Besada et al. (1982) was adopted here following the rationale of Fraga et al. (2011), which is the one followed in three of the last new Gambierdiscus species descriptions (Fraga et al. 2011; Nishimura et al. 2014; Fraga and Rodríguez 2014). The issue of plates' nomenclature is the subject of ongoing discussions. For detailed discussions regarding different nomenclatural interpretations see Fraga et al. (2011) and Gómez et al. (2015).

This article is protected by copyright. All rights reserved. 


\section{DNA extraction, amplification and sequencing}

For molecular analyses, $2 \mathrm{ml}$ of dense culture were pelleted by centrifugation and genomic DNA was extracted with a DNeasy Plant Mini DNA extraction kit (Qiagen, Hilden, Germany) following the manufacturer's instructions. The loci encoding the LSU rRNA regions D1-D2 and D8-D10 were amplified through Polymerase Chain Reaction (PCR) with the primers pairs D2C-D1R (Scholin et al. 1994) and FD8-RB (Chinain et al. 1999) respectively. The ITS region (ITS1-5.8 S-ITS2 rDNA) was amplified employing primers ITS1F and ITS1R (Leaw et al. 2001). The final PCR reaction contained $20 \mu \mathrm{l}$ of ultrapure water, $5 \mu \mathrm{l}$ of extracted DNA, $2.5 \mu \mathrm{l}\left(10 \mathrm{pmol} \mu \mathrm{l}^{-1}\right)$ of each primer and $20 \mu \mathrm{l}$ of a BioMix (Bioline, London, UK). The PCR amplification was carried out in a BIOER TC-24/H(b) thermocycler (BIOER Technology Co., Hangzhou, China) and cycling conditions were as follows: one cycle at $95^{\circ} \mathrm{C}$ for $2 \mathrm{~min}, 50{ }^{\circ} \mathrm{C}$ for $30 \mathrm{~s}$ and $72{ }^{\circ} \mathrm{C}$ for $45 \mathrm{~s} ; 35$ cycles at $94{ }^{\circ} \mathrm{C}$ for $30 \mathrm{~s}, 50^{\circ} \mathrm{C}$ for $90 \mathrm{~s}$ and $72^{\circ} \mathrm{C}$ for $30 \mathrm{~s}$; and a final elongation step of $72^{\circ} \mathrm{C}$ for $10 \mathrm{~min}$.

PCR products were purified using the kit MultiScreen HTS PCR 96-well filtration system (Merck-Millipore Corp.) and quantified with the spectrophotometer Nanodrop. For sequencing reaction (forward and reverse directions) the BigDye Terminator v3.1 Cycle Sequencing Kit (Applied Biosystems) was employed, and the reading was undertaken with the automatic sequencer ABI PRISM 3130xl Genetic Analyzer. The sequences were then edited using BioEdit v7.0.9 software (Hall 1999). For the ITS region three independent PCRs were run and sequenced, checking that in all cases the same sequence was recovered.

\section{Phylogeny, genetic distance and ITS2 secondary structure}

Two datasets were constructed for the phylogenetic analyses, one for the LSU rDNA D1-D2 region and the other one for the D8-D10 region. Datasets consisted of all available sequences from strains of Fukuyoa. The accession numbers and the strains they correspond to are given in the labels of the terminal nodes of the trees. Sequences from both datasets were aligned using the MUSCLE algorithm (Edgar 2004), with default settings, as implemented in MEGA 6 software (Tamura et al. 2013). Maximum likelihood (ML) and maximum parsimony (MP) analyses were conducted in MEGA 6 . The model $\mathrm{K} 2+\mathrm{G}$ was selected as the best for both the D1-D2 and D8-D10 datasets in the phylogenetic model selection for the maximum likelihood (ML) analysis (5 gamma categories; gamma shape parameter 0.58 and 200.0 for D1-D3 and D8-D10, respectively). MP trees were obtained with the subtree pruning and regrafting algorithm (search level 1) in which the initial trees were obtained by the random addition of sequences (10 replicates). Bootstrap values were estimated from 5000 replicates.

Uncorrected genetic distance $(p)$ values were calculated among ITS region sequences available for Fukuyoa strains, including the one obtained from Dn135EHU. The nucleotides of the 5' and 3' ends of the sequences corresponding to the SSU and LSU rDNA regions, respectively, were deleted before the analyses. Sequences were aligned with the ClustalW algorithm (open and extended gap penalties were set to10.0 and 5.0, respectively, in both the pair-wise and multiple alignments; Litaker et al. 2007) and the $p$-values calculated in MEGA 6 software. Both Complete and Pairwise deletion options were computed. In the former, a gap or an uncertain nucleotide at any position in the alignment results in the deletion of this position over the whole alignment, whereas in the latter option, this position is only deleted for the pair of sequences under comparison. Additionally, we calculated the $p$-values considering substitutions, gaps and ambiguous bases.

Changes in the compensatory base pairing arrangements in the secondary structure of ITS2 region, which can reveal sexual incompatibility (Coleman 2009), were analyzed. The ITS2 secondary structure was predicted by homology modeling (Wolf et al. 2005a) for the

This article is protected by copyright. All rights reserved. 
available Fukuyoa sequences. Possible homology to the ITS2 secondary structure of Gambierdiscus caribaeus (accession number HE775087), available from ITS2-Database version v.5 (Ankenbrand et al. 2015), was explored. Structures were visualized with VARNA (Darty et al. 2009) and then alignment was performed with both 4SALE (Seibel et al. 2006) and ITS2-Database version v.5 (Ankenbrand et al. 2015). Finally, the compensatory and hemi compensatory base changes (CBC and hemi-CBC) were identified using the software CBCAanalyzer (Wolf et al. 2005b).

\section{Toxin analyses}

Extraction. Cells of $F$. paulensis strain Dn135EHU were grown in $75 \mathrm{~cm}^{2}$ NunclonTM culture flasks containing $60 \mathrm{ml}$ of medium (f/4) for CTXs characterization. Culture at early stationary phase was filtered (final volume of $1989 \mathrm{ml}$ ) through Whatman GF/C glass fiber filters to harvest cells. A lugol-fixed aliquot was collected to determine cell density under the light microscope using a Sedgewick-Rafter chamber.

The filter containing the cells was extracted twice in $\mathrm{MeOH}(7 \mathrm{ml}$ for a total biomass of $2.95 \times 10^{7}$ cells) under sonication and centrifugation at $5065 \mathrm{~g}$ for $10 \mathrm{~min}$ at $10^{\circ} \mathrm{C}$. An aliquot of $5 \mathrm{ml}$ of the extract was evaporated and then a solvent partition was applied to the resulting residue using $5 \mathrm{ml}$ of dichloromethane $\left(\mathrm{CH}_{2} \mathrm{Cl}_{2}\right)$ and $2 \times 2.5 \mathrm{ml}$ of aqueous $\mathrm{MeOH}$ (MeOH: $\mathrm{H}_{2} \mathrm{O}$ 60:40), according to the procedure recommended by Satake et al. (1993). During liquid-liquid partitions CTXs and MTXs compounds were recovered in the Dichloromethane and aqueous-MeOH phases respectively, both phases were handled with extreme care in order to limit carryover of MTX-like compounds into de dichloromethane phase and vice versa.

Mouse bioassay (MBA). Healthy male Swiss mice NMRI weight $20 \pm 1 \mathrm{~g}$ were used. The stock colony for the assay is managed following the Council Directive (EC 2007) on the approximation of laws, regulations and administrative provisions of the Member States regarding the protection of animals used for experimental and other purposes. Aliquots of 2 $\mathrm{ml}$ of the original extract, the dichloromethane and aqueous methanol soluble fractions, as well as blanks of each of those solvents, were dried under vacuum and resuspended in aqueous Tween $601 \%$. Mice were intraperitoneally injected with $1 \mathrm{ml}$ of Tween solution. One mouse was employed for each one of the five samples: three samples from the $F$. paulensis extract (unpartitioned extract and the $\mathrm{MeOH} 60 \%$ and Dichloromethane fractions from the partition) and two from the blank samples (MeOH $60 \%$ and Dichloromethane). After inoculation, mice were observed over 24 hours with food and water provided ad libitum, paying attention to toxicity signs and death times. Signs of ciguatoxicity include: inactivity, piloerection, vasodilatation in ears, cyanosis of tail, feet and muzzle, unsteady gait, tremor/convulsive jumping, hypothermia, dyspnea with gasping, severe diarrhea, hypersalivation, lacrimation and death (Lewis and Sellin 1993).

Liquid Chromatography coupled with High Resolution Mass Spectrometry (LC-HRMS). Mass spectrometry analysis were performed using a Thermo Scientific Dionex High-Speed LC coupled to an Exactive mass spectrometer, equipped with an Orbitrap mass analyzer an a HESI-II probe for electrospray ionization. The instrument was mass calibrated for positive and negative modes, and the capillary and tube lens voltages were also optimized, using the automated script within the Exactive acquisition software in both cases. HR full MS experiments were acquired in the mass range from 500 to $1,500 \mathrm{~m} / \mathrm{z}$ at a resolving power of 100,000 . The mass spectrometer was operated in positive mode for the monitoring of sodium adduct ions $\left([\mathrm{M}+\mathrm{Na}]^{+}\right)$. Calculation of elemental formulae of ions contained in HRMS

This article is protected by copyright. All rights reserved. 
spectra was performed by using the most intense ion of each ion cluster. A mass tolerance of $10 \mathrm{ppm}$ was used and the isotopic pattern of each ion cluster was considered in assigning molecular formulae. Toxins were separated on an Acquity BEH C18 column $(2.1 \times 100 \mathrm{~mm}$, $1.7 \mu \mathrm{m}$ particle size) maintained at $40{ }^{\circ} \mathrm{C}$, at a flow rate $300 \mu 1 \mathrm{~min}^{-1}$. The mobile phase consisted of (A) $5 \mathrm{mM}$ ammonium formate $0.1 \%$ formic and (B) $100 \% \mathrm{MeOH}$. A linear gradient elution from 78 to $88 \% \mathrm{~B}$ was run $12 \mathrm{~min}, 88 \% \mathrm{~B}$ was held for $4 \mathrm{~min}$, then decreased to $78 \% \mathrm{~B}$ in $0.1 \mathrm{~min}$ and this percentage held until min 20 . For toxins identification a standard solution of CTX4A, CTX4B, 52-epi-54-deoxy CTX1B, 54-deoxy CTX1B and

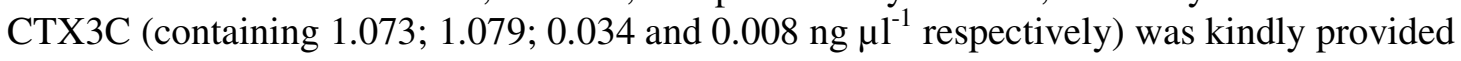
by professor Yassumoto.

\section{RESULTS}

Cells of Fukuyoa paulensis appeared in low numbers in the sample from the Formentera Island. The accompanying dinoflagellates in the sample included Ostreopsis sp., Coolia cf. canariensis, C. monotis, Prorocentrum lima and P. cf. belizeanum. Fukuyoa paulensis was absent from another sample from the close island of Ibiza (Fig. S1).

\section{Morphology}

Cultured cells (clonal strain Dn135EHU) were laterally compressed, 49 $\pm 11(35-76) \mu \mathrm{m}$ in length, $30 \pm 7$ (24-38) $\mu \mathrm{m}$ in width and $41 \pm 8$ (31-67) $\mu \mathrm{m}$ in depth (Table 1). Cells were globular in lateral view and oval both in antero-posterior and in dorso-ventral view, with a degree of lateral compression, measured as the depth/width ratio, of 1.29, and a length/width ratio of 1.28 as a measure of the level of antero-posterior compression. Size variability was smaller when the culture was first established, while smaller cells appeared latter (Fig. 1A). However, two discrete cell-size classes could not be distinguished (not shown). Numerous plastids radiated from the interior to the cell periphery and most of them were forked in their distal extreme (Fig. 1B). Cysts were easily found in aged cultures (Fig. 1C).

Cell surface was smooth, non-areolated and pores (average 35.5 pores $100 \mu \mathrm{m}^{-2}$ ) were present in all plates (Fig. 2, 3). Pores were evenly distributed except in plates' growing bands where they were absent. Cingular plates also bore pores but they were not evenly distributed. Pores were round with an average diameter of $0.35 \mu \mathrm{m}(\mathrm{n}=150)$. The inner view of the theca revealed an ultrastructure of the pores composed of a hymen with small perforations (Fig. $3 \mathrm{C})$.

Plate formula was Po, 4', 6"', 6c, ?s, 5"', 2"'”. The plate overlap pattern is depicted in Fig. 4. The epitheca consisted of four apical and six precingular plates and the apical pore plate (Po). First apical plate (1') closed the sulcus on its anterior part (Fig. 2A, B). It was approximately 3 times as long as wide and its anterior half was wedge shaped. The second, third and fourth apical plates surrounded the Po plate (Fig. 2F). The 4' plate was the largest of the apical plates. It was oblong and limited with plates 6" and 1'in its antapical part, with plates 2', 3' and Po in its apical part and plates 1" and 5"' in its laterals (Fig. 2B, G). The second largest apical plate was $2^{\prime}$, then $3^{\prime}$ and the smallest was the $1^{\prime}$. The suture between 2' and $3^{\prime}$ ran straight in dorso-ventral direction (Fig. 2F). Plate 2' was more elongated than 3' and extended more to the ventral part. Among precingular plates, $2^{\prime \prime}$ and 5" were the largest; 1 "', 3" and 4" were medium sized and 6" was the smallest. Plates 2" and 5" occupied most of the epitheca's laterals (Fig. 2H, I). Plate 2" was four-sided and 5" five-sided. Plates 3" and 4 " were trapezoidal, plate 6" was more or less quadrangular and plate 1" was more or less sail-shaped, with its ventral suture bend to the dorsum. The Po plate was centrally placed in the apex. It was elongated, with a length of $7.63 \mu \mathrm{m}$ and width of $4.07 \mu \mathrm{m}$ and oriented

This article is protected by copyright. All rights reserved. 
diagonally in apical view, being narrower to the ventral side (Fig. 3A-C). It bore a fishhookshaped slit and between 29 and 39 thecal pores. The hypotheca was composed by five postcingular and two antapical plates. Plates 2"'(five sided or half-oval shape if not angular) and 4"' (square shaped) were the largest and occupied most of the hypotheca laterals (Fig. 2I, J). Plates 1" " and 5 " "were triangle shaped and plate 3 "' was trapezoidal and occupied hypotheca's dorsal part. Plate 2"'” was pentagonal, dorso-ventraly elongated and occupied the antapex (Fig. 2D), whereas plate 1"'” was much smaller and more or less trapezoidal. The cingulum was deep, composed of 6 plates, ran equatorially (Fig. $2 \mathrm{H}$; note that cingulum seems more apical in Fig. 2I, J because the view is slightly antapical) and descended about 2 widths. Cingular lists usually appeared nearly closing the cingulum (Fig. 2A, D), probably as a result of a fixation artifact. Cingular lists after the sixth cingular plate were continued by lists in the transition and sulcal right posterior plates (Fig. 3D, E).

The broad sulcus was bordered, on its right margin, by plate $6^{\prime}$ in the epitheca and by plate 5" in the hypotheca. On its left margin, the sulcus was bordered by plates 1"' and $1^{\prime \prime \prime \prime}$. Plate 1'closed the sulcus apical end. On the antapical part of the sulcus, a third or half of Sp plate entered the sulcus and the rest of the plate extended into the hypotheca (Fig. 3E), with its posterior bent to the right, until a narrow contact with plate 4"' (nine cells observed with this contact versus a single cell observed without it). Sulcal lists were present on the margins of plates 6", 5"', $1^{\prime \prime \prime}$ and 1"'”'. In addition to these sulcal lists, other less developed lists could be observed within the sulcus, such as in the left margin of plate Sdp (Fig. 3D). Six sulcal plates could be observed (Sp, sulcal posterior plate; Sdp, sulcal right posterior plate; Ssp, sulcal left posterior plate; t, transition plate; Sda, sulcal right anterior plate; Ssa, sulcal left anterior plate) although the area between plates Ssa and Ssp could not be properly resolved (Fig. 3D, E). The sulcal list from the right margin of 1"'"' plate was the most developed, appearing sometimes in form of wing. The sulcal list in the margin of the sixth precingular plate extended slightly to the epitheca along the suture with plate 1'.

\section{Phylogeny, genetic distance and ITS2 secondary structure}

Sequences of 733, 863 and 495 nucleotides were obtained for the LSU D1-D2, D8-D10 and ITS regions, respectively (deposited in the European Nucleotide Archive ENA/GenBank/DDBJ under the Accession numbers LN880856, LN880857, LN880855) from the Mediterranean strain Dn135EHU. The LSU rDNA sequences (D1-D2, D8-D10) of the local strain were aligned with available sequences of Fukuyoa strains from the databases to infer phylogenetic relationships (Fig. 5, 6). The D1-D2 LSU rDNA tree comprised 13 sequences from 7 strains (Fig. 5) and the final dataset contained a total of 673 positions. The sequence from the local strain Dn135EHU clustered with the New Zealand, Australian and

Brazilian strains sharing identical sequences (strains CAWD210, NQAIF210 and VGO1185, respectively). This clade was the most distantly related from the others. The other three clades belonged to intragenomic variant sequences from single strains: one for strain Gyasu of $F$. yasumotoi, another for strain NOAA8 of $F$. ruetzleri and another for strain Go3C of $F$. cf. yasumotoi. Sequences of strains Gyasu and NOAA8 clustered together with moderate support (bootstrap values 80/69, ML/MP). The D8-D10 LSU rDNA tree comprised 13 sequences from 7 strains (Fig. 6) and there were a total of 823 positions in the final dataset. The sequence from Dn135EHU clustered with the New Zealand and Australian strains CAWD210 and NQAIF210 containing identical sequences. Another well-supported clade was formed by the four intragenomic sequence variants of strain NOAA8 and the sequence of strain NOAA22 of $F$. ruetzleri. The four intragenomic sequences of the strain Gyasu of $F$. yasumotoi clustered together only with moderate support (67/69) and these clustered with the sequence of strain IR4G of $F$. cf. yasumoto $i$ with moderate (72/74) support.

This article is protected by copyright. All rights reserved. 
The uncorrected genetic distances of the ITS region showed that Dn135EHU was the most distantly related among the different strains (Table 2). The Mediterranean strain was nearly equidistant to the other three strains, with $0.063-0.068$ substitutions per site under the complete deletion option and 0.175-0.188 without deleting sites.

The prediction of the secondary structure of the ITS2 showed that strains IRG4 of $F$. cf. yasumotoi and Gyasu of $F$. yasumoto $i$ showed nearly identical structures, with a single base differing in the hairpin loop of helix III. Helix I was conserved among the four strains and helix II was conserved among strains IRG4, Gyasu and NOAA8 (F. ruetzleri). Strain Dn135EHU ( $F$. paulensis) differed the most on the ITS2 secondary structure. CBCAanalyzer identified a hemi-CBC at the base of helix II in $F$. paulensis with respect to its relative strains (T-G in Dn135EHU vs. C-G in other strains) (Fig. 7).

\section{Toxin analyses}

Mouse bioassay (MBA). All the mice injected i. p. with samples obtained from Dn135EHU (original methanol 100\%, dichloromethane and aqueous methanol $60 \%$ fractions) showed symptoms typical of CTXs bioactivity, including dyspnoea, cyanosis, snout itching, hyperagitation and mouse rapidly developed lacrimation upon injection. Death happened by ataxia but differences were noted in length to time between injection and death. The mouse injected with the $\mathrm{MeOH} 60 \%$ fraction containing MTXs, died within 4 hours, whereas the mouse injected with the dicloromethane fraction, containing CTXs, died within 7 hours. The unpartitioned extract killed the mouse within 6 hours. Mice injected with blanks of solvents (MeOH 100\%, MeOH60\% and dichloromethane) survived and showed no symptoms.

Liquid Chromatography coupled with High Resolution Mass Spectrometry (LC-HRMS). Acquisition of masses from 500 to $1500 \mathrm{~m} / z$ aimed at searching the sodium pseudo-molecular ions $[\mathrm{M}+\mathrm{Na}]+$ (see in Table 3 the list with gambierol, gambieric acids and main CTXs congeners analyzed by LC-HRMS with their corresponding molecular ions masses).

Attending to the analyses of results from spectra data and precision of molecular formula assigned (Table 4), the signs of CTX activity observed in mice could be attributed to the presence in the Dn135EHU sample of trace amounts of compounds having mass characteristics of 54-deoxyCTX1B $\mathrm{m} / \mathrm{z} 1117.5880[\mathrm{M}+\mathrm{Na}]+$ in the RT $6.29 \mathrm{~min}$ in addition to gambieric acid A $\mathrm{m} / z, 1079.6458[\mathrm{M}+\mathrm{Na}]+$ in the RT $2.49 \mathrm{~min}$. Identification of those compounds in the sample is not conclusive since they were detected in trace levels. Further work is necessary in order to confirm the toxicity of the fraction containing 54-deoxyCTX1B. Chromatograms and mass spectrum recorded with the standard mix solution and Dn135EHU sample are shown in Fig. 8.

\section{DISCUSSION}

\section{Species delineation in Fukuyoa}

With a strain isolated from Singapore, Holmes (1998) described Gambierdiscus yasumotoi, which could easily be differentiated from the two previously described species, G. toxicus and G. belizeanus, which had a lenticular morphology. Later, Litaker et al. (2009) described G. ruetzleri, the second globular species, based on three strains from Belize and the Atlantic coast of USA. Although both species were morphologically very similar, some differences were pointed out. Gómez et al. (2015), apart from transferring the two previous species to the new genus Fukuyoa, described the third species, $F$. paulensis. The shape of the fourth apical plate ( $1^{\prime}$ in that study) was regarded as the main diagnostic character: broad as opposed to

This article is protected by copyright. All rights reserved. 
narrow in other species. However, in the $F$. paulensis strain Dn135EHU narrow 4' plates can be observed (Fig. 2B, G). In some cases, plate's projection from a dome-shaped epitheca makes 4' plate to look broader (e.g. Fig. 2F, note that focus is on the ventral part of 4'plate, whereas its dorsal end is out of focus). Slight morphometric differences can be observed among the strains analyzed to date (Table 1) within the genus Fukuyoa. The observed variation might partially be genetically controlled or environmentally driven. Discriminating among different levels of natural variability (interspecific differences, intraspecific geographic variation, inter-strain differences within a population, within-strain variability) is a difficult task to address. When dealing with morphologically (semi)cryptic species or lineages, the comparisons based on few strains entail the risk of confusing the different levels of variation. Furthermore, culture-induced artifacts or "non-natural" variation will enhance the complexity of this intrinsically complex scenario. Differences observed in the first 4 columns of Table 1 refer to $F$. paulensis strains with identical rDNA sequences. The overall view of the measurements from different studies shows a larger variability of this lineage. The measurements from the present study show smaller mean cell sizes for Dn135EHU (even smaller than $F$. ruetzleri) compared to the other $F$. paulensis strains, which show sizes within the range of $F$. yasumotoi. The ratio D/W is very consistent among strains Dn135EHU, VGO1185 and CAWD210 (closer to that of F. ruetzleri) but is smaller in NQAIF210 (closer to that of $F$. yasumotoi). On the other hand, the ratio L/W appears very inconsistent among strains. Other traits, such as Po plate's dimensions and pore numbers, also seem variable and of little use for distinguishing putative species.

When Gambierdiscus ruetzleri was described, its molecular differentiation respect to $G$. yasumotoi, based on SSU rDNA and LSU rDNA regions D1-D3 and D8-D10, was also subtle. They appeared as the most closely related species among those studied by Litaker et al. (2009). The genetic distance with the authentic strain of G. yasumotoi (Gyasu), based on the ITS region, was taken as the indicative of its species level differentiation (Litaker et al. 2007). Then, new Japanese strains, which were difficult to ascribe to one of the species, were analyzed (Go3 and IR4G, Nishimura et al. 2013). Although their genetic distance of the ITS region showed nearly within species level of divergence $(p=0.0252)$ with G.yasumotoi, reciprocal monophyly with respect to G. ruetzleri was not recovered in the phylogenetic analyses. This questioned their species level differentiation, or at least depicted a complex taxonomic scenario. Nishimura et al. (2013) also observed that G. ruetzleri vs. G. yasumotoi SSU rDNA distances were similar to the intraspecific divergence level of Gambierdiscus species, although the discriminating level of this marker is too low for species level considerations. Further, their status as distinct species was questioned in Murray et al. (2014). However, the ITS region-based genetic distance, which was the key element argued by Litaker et al. (2009) to recognize $G$. ruetzleri as a separate species, was not addressed.

More recently, Fukuyoa strains have been isolated from New Zealand (strain CAWD201; Rhodes et al. 2014), Australia (strain NQAIF210; Murray et al. 2014) and Brazil (strain VGO1185; Gómez et al. 2015). All these strains and the present Dn135EHU from the Mediterranean Sea share identical D1-D3 and D8-D10 LSU rDNA sequences (D8-D10 not available for VGO1185), showing they belong to the same species. However, the taxonomic interpretation reached in each case has differed. Rhodes et al. (2014) considered that their strain's characteristics resembled most closely, albeit not completely, to $F$. yasumotoi and named this ribotype Gambierdiscus cf. yasumotoi. Murray et al. (2014) pointed that caution was needed in delineating species within this group and, following a conservative criterion, the name G. yasumotoi was applied to strain NQAIF210. Subsequently, Gómez et al. (2015) described the new species $F$. paulensis for these strains. Despite the sister relationship between the $F$. paulensis sequences and $F$. yasumotoi and $F$. ruetzleri claimed by Gómez et al. (2015), more complex tree-topologies were recovered in other studies that included more

This article is protected by copyright. All rights reserved. 
sequences (Rhodes et al. 2014; Murray et al. 2014; this study). The ITS distances were not considered in the study of Gómez et al. (2015) and a morphological trait (broad 4' plate), shown in our study to be inconsistent, was used. Genetic distances based in the ITS region and the presence of CBCs in the ITS2 secondary structure, which can be taken as an indicative of sexual incompatibility (Coleman 2009), have been analyzed in this study. When aligned with the available sequences, the ITS-sequence of Dn135EHU showed two gaps of 18 and 33 positions, which could suggest that a pseudogene sequence was recovered.

However, three independent PCRs were run and the products were sequenced directly, what has the advantage of detecting the dominant intragenomic type (Stern et al. 2012). In the three cases identical sequences were recovered and, moreover, the ITS sequence available in the nucleotide databases from strain VGO1185 was also identical. After analyzing the ITS region in 81 dinoflagellate species, Litaker et al. (2007) observed a barcoding gap between the intraspecific and interespecific $p$-distaces, leading to the proposal of a $p$-value threshold of 0.04 substitutions per site as indicative of species level divergence. After the conclusions from the study by Litaker et al. (2007), the uncorrected genetic distances based on the ITS rDNA region suggest species level differentiation of the $F$. paulensis strains respect to the other known Fukuyoa strains (Table 2). However, ITS distances above the 0.04 threshold were not considered sufficient to recognize species in the absence of CBCs in the Alexandrium ostenfeldii complex (Kremp et al. 2014). In Fukuyoa, the analysis of the secondary structure of the ITS2 revealed the absence of CBCs among the four strains. A single hemi-CBC in the proximal part of helix II was detected in F. paulensis with respect to other strains. Only the existence of CBCs in conserved regions can be considered as a proxy of mating incompatibility (Müller et al. 2007; Coleman 2009; Caisová et al. 2011). However, the absence of CBCs does not preclude the existence of mating incompatibility, since the capability of crossing giving fertile progenies can be lost before the appearance of any CBC (Caisová et al. 2011).

In this complex scenario we could refer to a Fukuyoa-complex where $F$. paulensis is the most distantly related nominal species. The two alternative scenarios in the species complexes, a complex of cryptic species and a single species with different phylogenetic lineages, can be reflected in the analyses of Alexandrium tamarense and A. ostenfeldii complexes, respectively (John et al. 2014; Kremp et al. 2014). The situation of the Fukuyoa complex is more comparable to the scenario depicted for the A. ostenfeldii complex. In both Fukuyoa and $A$. ostenfeldii complexes different clades can be observed and the ITS distances of the most distant clade are above the threshold of 0.04 substitutions per site but below the most conservative value of 0.08 (Kremp et al. 2014). Additionally, no CBCs have been detected among clades and a hemi-CBC was present in the most divergent clade. In the absence of strong evidence of the existence of different species, and following a conservative criterion, Kremp et al. (2014) concluded that a single genetically structured species should be considered in the A. ostenfeldii complex. Nevertheless, since some of the elements agreed with the view of the existence of different species, the possibility of considering separate species in the future was left opened if more data and more refined criteria for species delimitation were obtained. The main circumstance that impacts the evaluation of the Fukuyoa complex is the low strains sampling. When Fukuyoa phylogenies are observed, it should be noted that clades are composed of intragenomic variant sequences of single strains. The strain sampling is especially limited if it is compared with the mentioned Alexandrium complexes (37 strains analyzed in the evaluation of the A. ostenfeldii complex and much more strains analyzed in the case of $A$. tamarense complex). A larger strains sampling could eventually help untangling the taxonomic scenario within Fukuyoa.

This article is protected by copyright. All rights reserved. 


\section{Biogeography}

The report of Fukuyoa paulensis in this study is the first observation of the warm water and toxigenic Gambierdiscus lineage in the western Mediterranean Sea and represents its highest latitude report worldwide.

Whereas several cells of Fukuyoa could be observed in the sample taken from Formentera, they were apparently absent from the sample taken $30 \mathrm{Km}$ far in the close island of Ibiza. Occasional benthos samples from Majorca and Minorca, the other islands from the same archipelago, were checked by us (e.g. Laza-Martinez et al. 2011; unpublished observations) and by other research groups (Vila et al. 2001; Penna et al. 2005) in other occasions and no Fukuyoa cells were reported. This suggests that Fukuyoa is not common in this area, although the available information is scarce for proper consideration.

Reports of Fukuyoa are very recent and include different ocean basins. After the original description of $F$. yasumotoi (Holmes 1998) with samples from Singapore, six sites from the western Pacific have been added to its known distribution: two southern Japanese islands (Nishimura et al. 2013) and one southern Korean island (Lee et al. 2014) in the Northern hemisphere, and northern New Zealand (Rhodes et al. 2014) and the Australian Great Barrier Reef (Murray et al. 2014) in the Southern hemisphere. Additionally, in the webpage of IFREMER (http://wwz.ifremer.fr/lerfbn; last accessed 15-11-2015) a SEM microphotograph of $F$. ruetzleri from New Caledonia is shown. Regarding the western Atlantic (including Caribbean Sea and Gulf of Mexico), its presence has been reported in four sites: F. yasumotoi from the Mexican Caribbean coast (Hernández-Becerril and AlmazánBecerril 2004); in the original description of F. ruetzleri, Litaker et al. (2009) isolated three strains from Belize and the USA Atlantic coast (North Carolina); F. ruetzleri was also reported from the northern Gulf of Mexico (Tester et al. 2013); and very recently, $F$. paulensis has been described from São Paulo, Brasil (Gómez et al. 2015). Also recently, $F$. yasumotoi has been reported from the northern Red Sea (Jordan) and Persian Gulf (Kuwait) (Saburova et al. 2013). The presence of "globular Gambierdiscus" cells was mentioned for the eastern Mediterranean Sea (Parsons et al. 2012). Most of the referred sites are tropical or subtropical, while the Jeju Island (Korea) and Cape Fear (North Carolina, USA) are warmtemperate areas, albeit under the influence of western boundary currents (Kuroshio and Gulf Stream Currents, respectively) that flow from lower latitudes.

The present strain of Fukuyoa was isolated from a temperate area, the western Mediterranean Sea. The spatial and temporal distribution of the sea surface temperature (SST) from this area was characterized in another work dealing with the distribution limits of Ostreopsis spp. in the Iberian Peninsula (Fig. 6 in David et al. 2012). It is interesting to note that the highest $75^{\text {th }}$ percentile of the SST coincided with the area where $F$. paulensis was observed in the present study. From the referred SST percentile it can be concluded that three months with SST above $23.5^{\circ} \mathrm{C}$ can be expected in this area. Similar or higher $75^{\text {th }}$ percentiles of the SST were calculated for south-eastern Tyrrhenian Sea and from Tunisia to the east (unpublished map covering a larger area). The locality also coincides with the $14{ }^{\circ} \mathrm{C}$ isotherm of February, which has been suggested to be the limit for the warm-water species in the Mediterranean Sea (Bianchi 2007). Seawater in the eastern basin of the Mediterranean Sea is markedly warmer (Bianchi 2007) and the few previous reports of Gambierdiscus and Fukuyoa in the Mediterranean Sea are recent and refer to that basin (records gathered in Fig. S1). Gambierdiscus cells were observed for the first time in the Mediterranean Sea in the island of Crete (Greece) and a morphological characterization was provided (Aligizaki and Nikolaidis 2008). Then, the observations in this area spanned the northern isle of Salamina in Greece and Cyprus (Aligizaki et al. 2009) and, in the revision by Parson et al. (2012), the presence of cells of globular morphology (Fukuyoa) were also mentioned for this area. The

This article is protected by copyright. All rights reserved. 
study of Holland et al. (2013) about toxicity of Gambierdiscus species with strains of different origins, included a strain isolated in 2010 from Crete and identified as $G$.

carolinianus, providing a new report of an additional species for the eastern Mediterranean. Finally, in the work by Ismael (2014) the presence of Gambierdiscus sp. from the Egyptian Mediterranean coast was mentioned although no micrograph or additional information was given. In summary, at least three Gambierdiscus and Fukuyoa species are present in the eastern Mediterranean: Gambierdiscus sp., G. carolinianus and Fukuyoa sp. Strains from the former two showed low toxicity (Aligizaki et al. 2009; Holland et al. 2013, respectively) whereas the latter was not isolated in culture. Three possible ciguatera poisoning cases and the detection of ciguatoxin-like substances in fish from the coasts of Israel (Bentur and Spanier 2007) should be added to the mentioned reports.

Both enhanced growth and northward expansion of termophilic native Mediterranean species and settlement of new species of (sub)tropical affinities, that could enter through different ways, are expected for the Mediterranean Sea as a consequence of the global warming (Bianchi 2007). Biogeographically, the Mediterranean Sea is linked to the adjacent east Atlantic warm areas (Lusitania province; e. g. Briggs and Bowen 2012; Almada et al. 2013) through the natural connection of the Straits of Gibraltar. New species can enter the Mediterranean Sea through this Atlantic influx. Southward from Gibraltar in the Atlantic, three Gambierdiscus species (G. excentricus, G. silvae and G. australes) have been found in the Canary Islands, where punctual CFP cases have also been reported in the last years, and furthermore, G. excentricus was also observed in the adjacent Moroccan coast (Fraga et al. 2011; Fraga and Rodríguez 2014). On the opposite end of the Mediterranean Sea, the opening of the Suez Canal in 1869 supposed the connection with another biogeographic region (IndoPacific). Due to sea-level differences, the seawater flux is from the Red Sea to the Mediterranean. Gambierdiscus cells have been reported in the central Red Sea Saudi Arabian coast (Catania 2012) and G. cf. belizeanus and, more interestingly, F. yasumotoi cells have been isolated in the northern Red Sea (Saburova et al. 2013). Moreover, a case of ciguatera has been reported from the Egyptian Red Sea coast (de Aro et al. 2003). In addition to the two open connections with adjacent seas, other human-mediated introductions (ship ballast and fouling, aquaculture, aquariology...) can potentially introduce species to the Mediterranean Sea.

The process of increasing occurrence of warm-water species in the Mediterranean Sea has been regarded as an undergoing process of 'tropicalization' (Bianchi 2007). This process is documented for several conspicuous elements of the biota (references in Bianchi 2007). Even if a parallel process can be expected for the more cryptic microscopic groups, the lack of thorough historical data for them impedes to judge if the new records (e.g. the one from this study or the others mentioned from the eastern Mediterranean Sea for the case of Gambierdiscus spp.) refer to previously overlooked native species or alien species to these areas. However, in the case of Fukuyoa, it is interesting to note that four strains from distant origins (Mediterranean Sea, Southern Atlantic Ocean and Pacific Ocean) share identical rDNA sequences, especially as we are dealing with a microalga associated to the benthos, which is expected to show larger geographical variability than planktonic species, as it is expected to be less vagile (Penna et al. 2010). The production of cysts observed in strain Dn135EHU might facilitate its successful long distance-dispersal through different vectors.

\section{Toxicity}

Both MTX and CTX compounds were deduced in the present strain of $F$. paulensis Dn135EHU from the MBA. The LC-HRMS analysis showed trace amounts of a compound having mass characteristics of 54-deoxyCTX1B (CTX-3) in addition to gambieric acid A, a compound shown not to be toxic to mice when injected intraperitoneally at a dose of $1 \mathrm{mg} / \mathrm{kg}$

This article is protected by copyright. All rights reserved. 
(Nagai et al. 1993). The only other report of CTX in a Fukuyoa strain refers to the detection of 2,3-dihydroxyCTX3C in the strain NOAA3 of $F$. ruetzleri (Roeder et al. 2010), showing that both CTX1B and CTX3C congeners can be produced within this genus. Rhodes et al. (2014) analyzed strain CAWD210 of $F$. paulensis, which shows LSU sequences identical to Dn135EHU, but did not detect CTX; instead they detected a putative MTX analogue with the same mass as MTX-3. It should be noted that a much larger biomass has been analyzed in the present study. Strain VGO1185 of $F$. paulensis, also sharing identical LSU and ITS sequences, was analyzed for presence of CTX through the mouse neuroblastoma assay with negative results (Gómez et al. 2015). Although strain Dn135EHU produced only trace amounts of CTX, it is indicative of the potential of representatives of the genus Fukuyoa to produce this group of toxins. From the observed intraspecific variability on toxicity in various species of Gambierdiscus (Holland et al. 2013), it cannot be ruled out that other strains of the present species of Fukuyoa can produce larger CTX amounts.

\section{Conclusion}

In conclusion, in this study we show the potential of the western Mediterranean Sea to harbor toxic Fukuyoa populations. Considering that in the areas where Fukuyoa cells have been detected, Gambierdiscus species have also been reported, the present finding could also be indicative of the potential of the western Mediterranean to eventually harbor Gambierdiscus populations. The detection of CTX in Fukuyoa strains shows that the genes implicated in the CTX production evolved before the divergence of the lenticular and globular forms, and that both Gambierdiscus and Fukuyoa, as the Gambierdiscus lineage, should be considered when as contributing to ciguatera fish poisoning.

The sampling within the Fukuyoa complex is still too limited. The delineation of the intraspecific and interespecific limits in morphological and/or molecular traits, in order to define proper species diagnoses, stands as a difficult task to address which is still not properly resolved in this genus. The current morphological circumscriptions have been revealed to be of little applicability. At the present state of knowledge, we consider that Fukuyoa strains should be considered morphologically cryptic. The uncertainty about species limits is characteristic of recently diverged lineages (Leliaert et al. 2014). Different lineages at different speciation stages might be present within this complex, where $F$. paulensis stands as the most distantly related nominal species.

\section{AKCNOWLEDGMENTS}

Financial support for this research was provided by the Basque Government (project IT69913). A grant from the University of the Basque Country (UPV/EHU) to H. David also supported this study. The authors wish to thank Iratxe Izpizua for the microscope-work, Fabiola Arévalo from INTECMAR for the mouse bioassays and Santiago Fraga for his comments about plates nomenclature. The initial manuscript was also improbed with the comments of anonimous reviewers. The E.M. work and genetic sequencing were performed in the unit of Analytical and High-Resolution Microscopy in Biomedicine, and the Sequencing and Genotyping Unit from SGIker services of the UPV/EHU.

This article is protected by copyright. All rights reserved. 


\section{LITERATURE CITED}

Adachi, R. \& Fukuyo, Y. 1979. The thecal structure of the marine toxic dinoflagellate Gambierdiscus toxicus gen. et sp. nov. collected in a ciguatera endemic area. Bull. Japan. Soc. Sci. Fish., 45:67-71.

Aligizaki, K. \& Nikolaidis, G. 2008. Morphological identification of two tropical dinoflagellates of the genera Gambierdiscus and Sinophysis in the Mediterranean Sea. J. Biol. Res. Thessaloniki, 9:75-82.

Aligizaki, K., Katikou, P. \& Nikolaidis, G. 2009. Toxic benthic dinoflagellates spreading and potential risk in the Mediterranean Sea. In: 7th International Conference in Molluscan Shellfish Safety, www.symposcience.org.

Almada, V. C., Toledo, J. F., Brito, A., Levy, A., Floeter, S. R., Robalo, J. I., Martins, J., \& Almada, F. 2013. Complex origins of the Lusitania biogeographic province and northeastern Atlantic fishes. Front. Biogeogr., 5:20-28.

Ankenbrand, M. J., Keller, A., Wolf, M., Schultz, J. \& Förster F. 2015. ITS2 database V: Twice as much. Mol. Biol. Evol. (in press), doi:10.1093/molbev/msv174

Bentur, Y. \& Spanier, E., 2007. Ciguatoxin-like substances in edible fish of the eastern Mediterranean. Clin. Toxicol., 45:695-700.

Besada, E. G., Loeblich, L. A. \& Loeblich III, A. R. 1982. Observations on tropical, benthic dinoflagellates from ciguatera-endemic areas: Coolia, Gambierdiscus, and Ostreopsis. Bull. Mar. Sci., 32:723-735.

Bianchi, C. N. 2007. Biodiversity issues for the forthcoming tropical Mediterranean Sea. Hydrobiologia, 580:7-21.

Briggs, J. C. \& Bowen, B. W. 2012. A realignment of marine biogeographic provinces with particular reference to fish distributions. J. Biogeogr., 39:12-30.

Caisová, L., Marin, B. \& Melkonian, M. 2011. A close-up view on ITS2 evolution and speciation- a case study in the Ulvophyceae (Chlorophyta, Viridiplantae). BMC Evol. Biol.,11: 262.

Catania, D. 2012. The prevalence of benthic dinoflagellates associated with ciguatera in the Central Red Sea. MS thesis. King Abdullah University of Science and Technology, Thuwal, Saudi Arabia. 40 p.

Chinain, M., Faust, M. A. \& Pauillac, S. 1999. Morphology and molecular analyses of three toxic species of Gambierdiscus (Dinophyceae): G. pacificus, sp. nov., G. australes, sp. nov., and G. polynesiensis, sp. nov. J. Phycol., 35:1282-96.

Coleman, A. 2009. Is there a molecular key to the level of "biological species" in eukaryotes? A DNA guide. Mol. Phylogenet. Evol., 50:197-203.

Darty, K., Denise, A. \& Ponty, Y. 2009. VARNA: Interactive drawing and editing of the RNA secondary structure. Bioinformatics, 25:1974-1975.

David, H., Ganzedo, U., Laza-Martínez, A. \& Orive, E. 2012. Relationships between the presence of Ostreopsis (Dinophyceae) in the Atlantic coast of the Iberian Peninsula and sea-surface temperature. Cryptogamie Algol., 33:199-207.

de Haro, L., Pommier, P. \& Valli, M. 2003. Emergence of imported ciguatera in Europe: report of 18 cases at the Poison Control Centre of Marseille. Clin. Toxicol., 41:927-930.

Edgar, R. C. 2004. MUSCLE: multiple sequence alignment with high accuracy and high throughput. Nucleic Acids Res., 32:1792-1797.

Faust, M. A. 1995. Observation of sand-dwelling toxic dinoflagellates (Dinophyceae) from widely differing sites, including two new species. J. Phycol., 31:996-1003.

Fraga, S. \& Rodríguez, F. 2014. Genus Gambierdiscus in the Canary Islands (NE Atlantic Ocean) with description of Gambierdiscus silvae sp. nov., a new potentially toxic epiphytic benthic dinoflagellate. Protist, 165:839-853.

This article is protected by copyright. All rights reserved. 
Fraga, S., Rodríguez, F., Caillaud, A., Diogène, J., Raho, N. \& Zapata, M. 2011.

Gambierdiscus excentricus sp. nov. (Dinophyceae), a benthic toxic dinoflagellate from the Canary Islands (NE Atlantic Ocean). Harmful Algae, 11:10-22.

Gómez, F., Qiu, D., Lopes, R. M. \& Lin, S. 2015. Fukuyoa paulensis gen. et sp. nov., a new genus for the globular species of the dinoflagellate Gambierdiscus (Dinophyceae). PLoS ONE, DOI 10.1371/journal.pone.0119676.

Guillard, R. R. L. \& Ryther, J. H. 1962. Studies of marine planktonic diatoms. I. Cyclotella nana Hustedt, and Detonula confervacea (Cleve) Gran. Can. J. Microbiol., 8:229-239.

Hall, T. A. 1999. BioEdit: a user-friendly biological sequence alignment editor and analysis program for Windows 95/98/NT. Nucl. Acids Symp. Ser., 41:95-8.

Hernández-Becerril, D. \& Almazán-Becerril, A., 2004. Especies de dinoflagelados del género Gambierdiscus (Dinophyceae) del Mar Caribe mexicano. Rev. Biol. Trop., 52:77-87.

Holland, W. C., Litaker, R. W., Tomas, C. R., Kibler, S. R., Place, A. R., Davenport, E. D. \& Tester, P. A. 2013. Differences in the toxicity of six Gambierdiscus (Dinophyceae) species measured using an in vitro human erythrocyte lysis assay. Toxicon, 65:15-33.

Holmes, M. J. 1998. Gambierdiscus yasumotoi sp. nov. (Dinophyceae), a toxic benthic dinoflagellate from southeastern Asia. J. Phycol., 34:661-668.

Ismael, A. A. 2014. First record of Coolia monotis Meunier along Alexandria coast-Egypt. Egypt. J. Aquat. Res., 40:19-25.

Jeong, H. J., Lim, A. S., Jang, S. H., Yih, W. O., Kang, N. S., Lee, S. Y., Yoon, Y. D. \& Kim, H. S. 2012. First report of the epiphytic dinoflagellate Gambierdiscus caribaeus in the temperate waters off Jeju Island, Korea: morphology and molecular characterization. $J$. Eukaryot. Microbiol., 59:637-650.

John, U., Litaker, R. W., Montresor, M., Murray, S., Brosnahan, M. L. \& Anderson, D. M. 2014. Formal revision of the Alexandrium tamarense species complex (Dinophyceae) taxonomy: the introduction of five species with emphasis on molecular-based (rDNA) classification. Protist, 165:779-804.

Kibler, S. R., Litaker, R. W., Holland, W. C., Vandersea, M. W. \& Tester, P. A., 2012. Growth of eight Gambierdiscus (Dinophyceae) species: effects of temperature, salinity and irradiance. Harmful Algae, 19:1-14.

Kohli, G., Murray, S., Neilan, B., Rhodes, L., Harwood, T., Smith, K., Meyer, L., Capper, A., Brett, S. \& Hallegraeff, G. 2014. High abundance of the potentially maitotoxic dinoflagellate Gambierdiscus carpenteri in temperate waters of New South Wales, Australia. Harmful Algae, 39:134-145.

Kremp, A., Tahvanainen, P., Litaker, W., Krock, B., Suikkanen, S., Leaw, C. P. \& Tomas, C. 2014. Phylogenetic relationships, morphological variation, and toxin patterns in the Alexandrium ostenfeldii (Dinophyceae) complex: implications for species boundaries and identities. J. Phycol., 50:81-100.

Kuno, S., Kamikawa, R., Yoshimatsu, S., Sagara, T., Nishio, S. \& Sako, Y. 2010. Genetic diversity of Gambierdiscus spp. (Gonyaulacales, Dinophyceae) in Japanese coastal areas. Phycol. Res., 58:44-52.

Laza-Martínez, A., Orive, E. \& Miguel, I. 2011. Morphological and genetic characterization of benthic dinoflagellates of the genera Coolia, Ostreopsis and Prorocentrum from the south-eastern Bay of Biscay. Eur. J. Phycol., 46:1-21.

Leaw, C. P., Lim, P. T., Ahmad, A. \& Usup, G. 2001. Genetic diversity of Ostreopsis ovata (Dinophyceae) from Malaysia. Mar. Biotechnol., 3:246-255.

Lee, K. W., Kang, J. H., Baek, S. H., Choi, Y. U., Lee, D. W. \& Park, H. S. 2014. Toxicity of the dinoflagellate Gambierdiscus sp. toward the marine copepod Tigriopus japonicus. Harmful Algae, 37:62-67.

This article is protected by copyright. All rights reserved. 
Leliaert, F., Verbruggen, H., Vanormelingen, P., Steen, F., López-Bautista, J. M., Zuccarello, G. C. \& de Clerck, O. 2014. DNA-based species delimitation in algae. Eur. J. Phycol., 49: 179-196.

Lewis, R. J. \& Sellin, M. 1993. Recovery of ciguatoxin from fish flesh. Toxicon, 31:13331336.

Litaker, R. W, Vandersea, M. W., Kibler, S. R., Reece, K. S., Stokes, N. A., Lutzoni, F. M., Yonish, B. A. , West, M. A., Black, M. N. D. \& Tester, P. A. 2007. Recognizing dinoflagellate species using ITS rDNA sequences. J. Phycol., 43: 344-355.

Litaker, R. W., Vandersea, M. W., Faust, M. A., Kibler, S. R., Chinain, M., Holmes, M. J., Holland, W. C. \& Tester, P. A. 2009. Taxonomy of Gambierdiscus including four new species, Gambierdiscus caribeaeus, Gambierdiscus carolinianus, Gambierdiscus carpenteri and Gambierdiscus ruetzleri (Gonyaulacales, Dinophyceae). Phycologia, 45:344-390.

Litaker, R. W., Vandersea, M. W., Faust, M. A., Kibler, S. R., Nau, A. W., Holland, W. C., Chinain, M., Holmes, M. J. \& Tester, P. A. 2010. Global distribution of ciguatera causing dinoflagellates in the genus Gambierdiscus. Toxicon, 56:711-730.

Müller, T., Philippi, N., Dan Dekar, T. Schultz, J. \& Wolf, M. 2007. Distinguishing species. RNA, 13:1469-1472.

Murray, S., Momigliano, P., Heimann, K. \& Blair, D. 2014. Molecular phylogenetics and morphology of Gambierdiscus yasumotoi from tropical eastern Australia. Harmful Algae, 39:242-252.

Nagai, H., Mikami, Y., Yazawa, K. Gonoi, T. \& Yasumoto, T. 1993. Biological activities of novel polyether antifungals, gambieric acids $\mathrm{A}$ and $\mathrm{B}$ from a marine dinoflagellate Gambierdiscus toxicus. J. Antibiot., 46:520-522.

Nishimura, T., Sato, S., Tawong, W., Sakanari, H., Uehara, K., Shah, M. M. R., Suda, S., Yasumoto, T., Taira, Y., Yamaguchi, H. \& Adachi, M. 2013. Genetic diversity and distribution of the ciguatera-causing dinoflagellate Gambierdiscus spp. (Dinophyceae) in coastal areas of Japan. PLoS ONE, 8:e60882. doi: 10.1371/journal.pone.0060882.

Nishimura, T., Sato, S., Tawong, W., Sakanari, H., Yamaguchi, H. \& Adachi, M. 2014. Morphology of Gambierdiscus scabrosus sp. nov. (Gonyaulacales): A new epiphitic dinoflagellate from coastal areas of Japan. J. Phycol., 50:506-514.

Parsons, M. L., Aligizaki, K., Bottein, M. Y. D., Fraga, S., Morton, S. L., Penna, A. \& Rhodes, L. 2012. Gambierdiscus and Ostreopsis: reassessment of the state of knowledge of their taxonomy, geography, ecophysiology, and toxicology. Harmful Algae, 14:107129.

Penna, A., Vila, M., Fraga, S., Giacobbe, M. G., Andreoni, F., Riobó, P. \& Vernesi, C. 2005. Characterization of Ostreopsis and Coolia (Dinophyceae) isolates in the western Mediterranean Sea based on morphology, toxicity and internal transcribed spacer $5.8 \mathrm{~s}$ rDNA sequences. J. Phycol., 41: 212-225.

Penna, A., Fraga, S., Battocchi, C., Casabianca, S., Riobó , P., Giacobbe, M. G. \& Vernesi, C. 2010. A phylogeography study of the toxic benthic genus Ostreopsis Schmidt. $J$. Biogeogr., 37:830-841.

Rhodes, L., Papiol, G., Smith, K. \& Harwood, T. 2014. Gambierdiscus cf. yasumotoi (Dinophyceae) isolated from New Zealand's sub-tropical northern coastal waters. N. Z. J. Mar. Fresh. Res., 48:303-310.

Roeder, K., Erler, K., Kibler, S., Tester, P., The, H. V., Nguyen-Ngoc, L., Gerdts, G. \& Luckas, B. 2010. Characteristic profiles of Ciguatera toxins in different strains of Gambierdiscus spp. Toxicon, 56:731-738.

Saburova, M., Polikarpov, I. \& Al-Yamani, F. 2013. New records of the genus Gambierdiscus in marginal seas of the Indian Ocean. Mar. Biodivers. Rec., 6:1-11.

This article is protected by copyright. All rights reserved. 
Satake, M., Murata, M. \& Yasumoto, T. 1993. Gambierol: a new toxic polyether compound isolated from the marine dinoflagellate Gambierdiscus toxicus. J. Am.Chem. Soc., 115:361-362.

Scholin, C. A., Herzog, M., Sogin, M. \& Anderson, D. M. 1994. Identification of group- and strain-specific genetic markers for globally distributed Alexadrium (Dinophyceae) II. Sequence analysis of a fragment of the LSU rRNA gene. J. Phycol., 30:999-1011.

Seibel, P. N., Müller, T., Dandekar, T., Schultz, J. \& Wolf, M. 2006. 4SALE- a tool for synchronous RNA sequence and secondary structure alignment and editing. BMC Bioinformatics, 7:498.

Stern, R. F., Andersen, R. A., Jameson, I., Küpper, F. C., Coffroth, M. A., Vaulot, D., Le Gall, F., Véron, B., Brand, J. J., Skelton, H., Kasai, F., Lilly, E. L. \& Keeling, P. J. 2012. Evaluating the ribosomal internal transcribed spacer (ITS) as a candidate dinoflagellate barcode marker. PLoS ONE 7(8): e42780. doi:10.1371/journal.pone.0042780.

Tamura, K., Stecher, G., Peterson, D., Filipski, A. \& Kumar, S. 2013. MEGA6: Molecular Evolutionary Genetics Analysis version 6.0. Mol. Biol. Evol., 30:2725-2729.

Tester, P. A., Feldman, R. L., Nau, A. W., Kibler, S. R. \& Litaker, R. W. 2010. Ciguatera fish poisoning and sea surface temperatures in the Caribbean Sea and the West Indies. Toxicon, 56:698-710.

Tester, P. A., Vandersea, M. W., Buckel, C. A., Kibler S. R., Holland, W. C., Davenport, E. D., Clark, R. D., Edwards, K. F., Taylor, J. C., Pluym, J. L. V., Hickerson, E. L. \& Litaker, R. W. 2013. Gambierdiscus (Dinophyceae) species diversity in the Flower Garden Banks National Marine Sanctuary, Northern Gulf of Mexico, USA. Harmful Algae, 29:1-9.

Vila, M., Garcés, E. \& Masó, M. 2001. Potentially toxic epiphytic dinoflagellate assemblages on macroalgae in the NW Mediterranean. Aquat. Microb. Ecol., 26:51-60.

Wolf, M., Achtziger, M., Schultz, J., Dandekar, T. \& Müller, T. 2005a. Homology modeling revealed more than 20,000 rRNA internal transcribed spacer 2 (ITS2) secondary structures. RNA, 11:1616-1623.

Wolf, M., Friedrich, J., Dandekar, T. \& Müller, T. 2005b. CBCAnalyzer: inferring phylogenies based on compensatory base changes in RNA secondary structures. In Silico Biol., 5:291-294.

Xu, Y., Richlen, M. L., Morton, S. L., Mak, Y. L., Chan, L. L., Tekiau, A. \& Anderson, D. M. 2014. Distribution, abundance and diversity of Gambierdiscus spp. from a ciguateraendemic area in Marakei, Republic of Kiribati. Harmful Algae, 34:56-68.

\section{FIGURE LEGENDS}

Fig. 1. Light microscopy images of Fukuyoa paulensis (strain Dn135EHU). A. Live cells in culture showing size variability. B. Confocal microscope image showing autofluorescence of plastids. C. A cyst from the bottom of the culture flask from an aged culture. Scale bars $=20$ $\mu \mathrm{m}(\mathrm{A}), 10 \mu \mathrm{m}(\mathrm{B}, \mathrm{C})$.

Fig. 2. Scanning electron (A-D, G-J) and light microscopy (E, F) images of Fukuyoa paulensis (strain Dn135EHU) showing general cell morphology and thecal plates. A. Cell in ventral view. B. Cell in anteroventral view. C. Cell in posteroventral view; note the sulcal lists (arrows). D. Cell in dorsal view. E. Confocal microscopy image of a calcofluor stained cell; left lateral view of the epitheca. F. Bright field light microscopy image of the epitheca. G. Right anterolateral view. H. Right lateral view. I. Left lateral view. J. Right posterolateral view. Scale bars $=10 \mu \mathrm{m}$.

This article is protected by copyright. All rights reserved. 
Fig. 3. Scanning electron microscopy images of Fukuyoa paulensis (strain Dn135EHU). A, B. Detail of the apical pore complex (Po) plate. C. Internal view of Po plate. The ultrastructure of the inner end of the thecal pores is shown (arrows). D, E. Detail of sulcal area. Note the ridge along the left margin of plate sdp (arrows). Sulcal right posterior plate (sdp), sulcal left posterior plate (ssp), sulcal left anterior plate (ssa), sulcal right anterior plate (sda), sulcal posterior plate (sp), flagelar pore (fp), transition plate (t). Scale bars $=2 \mu \mathrm{m}$ (AC), $5 \mu \mathrm{m}(\mathrm{D}, \mathrm{E})$.

Fig. 4. Plate overlap pattern for the epitheca (top) and hypotheca (down) deduced from SEM micrographs of Fukuyoa paulensis (strain Dn135EHU). Note that the projected plate-shapes in the drawing distort the real shapes, especially to the periphery, due to the globular cell morphology. For plates shapes refer to Fig. 2.

Fig. 5. Maximum likelihood (ML) unrooted tree inferred from large-subunit rDNA sequences (D1-D2 region) showing the position of strain Dn135EHU among the Fukuyoa strains. Values in the nodes indicate support in ML/MP analyses (bootstrap values estimated from 5000 replicates; values under 50 are marked with “-”). Labels in terminal nodes indicate accession numbers for sequences and strain in parenthesis.

Fig. 6. Maximum likelihood (ML) unrooted tree inferred from large-subunit rDNA sequences (D8-D10 region) showing the position of strain Dn135EHU among the Fukuyoa strains. Values in the nodes indicate support in ML/MP analyses (bootstrap values estimated from 5000 replicates). Labels in terminal nodes indicate accession numbers for sequences and strain in parenthesis.

Fig. 7. Predicted ITS2 secondary structure of Fukuyoa strains. A. Predicted structure of $F$. paulensis strain Dn135EHU (strain VGO1185 with identical sequence). B. Predicted structure of $F$. cf. yasumotoi strain IRG4. C. Helix III of the predicted structure of $F$. ruetzleri strain NOAA8. Helixes I and II for this strain were identical to that shown for strain IRG4. The arrows in A and B point at the hemi-CBC present between $F$. paulensis and the other Fukuyoa strains.

Fig. 8. LC-HRMS chromatograms (A, B) and mass spectra (D, E) obtained from positive ionization mode for strain Dn135EHU. LC-HRMS chromatogram (C) and mass spectra (F) obtained from positive ionization mode for CTX3 standard. A. At $m / z 1079.6383[\mathrm{M}+\mathrm{Na}]^{+}$ for Gambieric acid A. B, C. At $m / z, 1117.5812$ and $m / z, 1117.5787$ [M+Na] ${ }^{+}$for CTX3.

\section{SUPPORTING INFORMATION}

Fig. S1. Map centered in the Mediterranean Sea. The enlarged area shows the Balearic Islands, from where strain Dn135EHU of Fukuyoa paulensis was isolated. Reports from the literature of the Gambierdiscus lineage in the area are compiled (references in the text). Black stars indicate Fukuyoa observations, open stars indicate Gambierdiscus spp. and open triangles ciguatera poisoning cases. The black star from the eastern Mediterranean refers to an undetermined Greek site. The site in the north-Atlantic African coast refers to an undefined site in the Moroccan coast. BI, Balearic Islands; MS, Mediterranean Sea; SC, Suez Canal; SG, Straits of Gibraltar.

This article is protected by copyright. All rights reserved. 
Table 1. Morphometric comparison of Fukuyoa strains. Average \pm standard deviation, absolute range and number of measures are given where available.

\begin{tabular}{|c|c|c|c|c|c|c|c|c|c|c|}
\hline $\begin{array}{l}\text { Species }^{\mathrm{a}} \\
\text { (Strain) }\end{array}$ & $\begin{array}{c}\text { Fukuyoa }^{\mathrm{g}} \\
\text { paulensis }^{\mathrm{g}}\end{array}$ & $\begin{array}{c}\text { Fukuyoa } \\
\text { paulensis }^{\mathrm{g}}\end{array}$ & $\begin{array}{c}\text { G. cf. } \\
\text { yasumotoi }^{\mathrm{g}} \\
\text { (CAWD210) }^{\text {CAWD }}\end{array}$ & $\begin{array}{c}G . \\
\text { yasumotoi }^{\mathrm{g}}\end{array}$ & $\begin{array}{l}\text { G. ruetzleri } \\
\text { (NOAA8, 22, }\end{array}$ & \multicolumn{2}{|c|}{$\begin{array}{c}\text { G. yasumotoi } \\
{\text { (Gyasu })^{\mathrm{e}}}^{\text {(G) }}\end{array}$} & $\begin{array}{c}{ }^{\mathrm{b}} \mathrm{G} . \\
\text { yasumotoi }\end{array}$ & $\begin{array}{c}{ }^{\mathrm{b}} \mathrm{G} . \\
\text { yasumotoi }\end{array}$ & $\begin{array}{c}{ }^{\mathrm{b}} \mathrm{G} . \\
\text { yasumotoi }\end{array}$ \\
\hline Reference & this study & $\begin{array}{l}\text { Gómez et } \\
\text { al. } 2015\end{array}$ & $\begin{array}{c}\text { Rhodes et al. } \\
2014\end{array}$ & $\begin{array}{c}\text { Murray et al. } \\
2014\end{array}$ & $\begin{array}{c}\text { Litaker et al. } \\
2009\end{array}$ & $\begin{array}{c}\text { Holmes } \\
1998 ;\end{array}$ & $\begin{array}{l}\text { Litaker et } \\
\text { al. } 2009\end{array}$ & $\begin{array}{l}\text { Saburova } \\
\text { et al. } 2014\end{array}$ & $\begin{array}{l}\text { Saburova } \\
\text { et al. } 2014\end{array}$ & $\begin{array}{l}\text { Hernández } \\
\text {-Becerril } \\
\text { and } \\
\text { Almazán- } \\
\text { Becerril } \\
2004\end{array}$ \\
\hline Origin & $\begin{array}{c}\text { Western } \\
\text { Mediterranean } \\
\text { Sea }\end{array}$ & Brazil & New Zealand & $\begin{array}{c}\text { NE. } \\
\text { Australia }\end{array}$ & $\begin{array}{l}\text { Belize, } \\
\text { N. Carolina } \\
\text { (USA) }\end{array}$ & \multicolumn{2}{|c|}{ Singapore } & Kuwait & Jordan & $\begin{array}{c}\text { Caribbean } \\
\text { Mexico }\end{array}$ \\
\hline $\begin{array}{l}\text { Length (antero- } \\
\text { posterior axis) }\end{array}$ & $\begin{array}{l}48.9 \pm 10.9 \\
(35-76) \\
(n=100)\end{array}$ & $\begin{array}{l}56 \pm 3 \\
(51-62)\end{array}$ & $\begin{array}{l}59.8 \pm 7.5 \\
(54.3-67.3) \\
(n=20)\end{array}$ & $51(49-54)$ & $\begin{array}{l}51.6 \pm 4.9 \\
(45.1-59.6) \\
(n=14)\end{array}$ & $\begin{array}{l}53 \pm 0.6 \\
(45-63) \\
(n=51)\end{array}$ & $\begin{array}{l}62.4 \pm 4.3 \\
(54.4-68.6) \\
(n=14)\end{array}$ & $\begin{array}{l}61.7 \pm 6.2 \\
(49-70) \\
(n=20)\end{array}$ & $\begin{array}{l}62.9 \pm 6.8 \\
(55-72) \\
(n=7)\end{array}$ & \\
\hline $\begin{array}{l}\text { Depth (dorso- } \\
\text { ventral axis) }\end{array}$ & $\begin{array}{l}40.8 \pm 8.2 \\
(31-67) \\
(n=123)\end{array}$ & $\begin{array}{l}50 \pm 3 \\
(45-56)\end{array}$ & $\begin{array}{l}54.8 \pm 5.7 \\
(49.1-60.5) \\
(n=20)\end{array}$ & $49(44-54)$ & $\begin{array}{l}45.5 \pm 3.3 \\
(41.7-55.0) \\
(n=12)\end{array}$ & $\begin{array}{l}50 \pm 1 \\
(43-61) \\
(n=17)\end{array}$ & $\begin{array}{l}56.8 \pm 5.6 \\
(48.7-66.5) \\
(n=14)\end{array}$ & $\begin{array}{l}62.9 \pm 4.4 \\
(54-73) \\
(n=30)\end{array}$ & $\begin{array}{l}62.6 \pm 6.1 \\
(54-71) \\
(n=7)\end{array}$ & $60-63$ \\
\hline
\end{tabular}




\begin{tabular}{|c|c|c|c|c|c|c|c|c|c|c|}
\hline $\begin{array}{l}\text { Width } \\
\text { (transdiametral } \\
\text { axis) }\end{array}$ & $\begin{array}{l}30.5 \pm 6.6 \\
(24-38) \\
(n=60)\end{array}$ & $\begin{array}{l}45 \pm 2 \\
(41-48)\end{array}$ & $\begin{array}{l}42.5 \pm 4.1 \\
(38.4-46.6) \\
(n=20)\end{array}$ & $45(40-49)$ & $\begin{array}{l}35.7 \pm 3.0 \\
(30.9-42.2) \\
(n=12)\end{array}$ & $\begin{array}{l}44 \pm 70.8 \\
(38-50) \\
(n=17)\end{array}$ & $\begin{array}{l}51.7 \pm 5.6 \\
(42.8-60.1) \\
(n=14)\end{array}$ & $\begin{array}{l}54.1 \pm 5.1 \\
(46-61) \\
(n=9)\end{array}$ & $\begin{array}{l}54.7 \pm 1.5 \\
(53-56) \\
(n=3)\end{array}$ & $44-48$ \\
\hline $\mathrm{D} / \mathrm{W}$ & $1.29(\mathrm{n}=48)$ & $\sim 1.2$ & 1.29 & 1.08 & 1.35 & $\begin{array}{l}1.14 \\
(n=17)\end{array}$ & 1.10 & 1.28 & 1.14 & \\
\hline $\mathrm{L} / \mathrm{W}$ & $1.28(\mathrm{n}=10)$ & & 1.41 & 1.13 & 1.45 & & 1.21 & & & \\
\hline Po plate length & 7.6 & $10-12$ & $9.9^{c}$ & $\sim 8-9$ & $8.4 \pm 1.2$ & $\begin{array}{l}7.6 \pm 0.2 \\
(7.0-8.6) \\
(n=13)\end{array}$ & & \multicolumn{2}{|c|}{$9.2-9.5^{f}$} & 10 \\
\hline Po plate width & 4.1 & $6-7$ & $4.6^{c}$ & $4^{c}$ & $3.9 \pm 0.9$ & & & \multicolumn{2}{|c|}{$3.8-4.2^{f}$} & $5.5^{\mathrm{c}}$ \\
\hline $\begin{array}{l}\text { Pores number } \\
\text { in Po plate }\end{array}$ & $29-39$ & $30-39^{c}$ & & $33-45$ & $36 \pm 4.5$ & $26^{c}$ & & \multicolumn{2}{|c|}{$\begin{array}{c}37.1 \pm 3.6^{\mathrm{f}} \\
(33-42)(n=8)\end{array}$} & $44^{\mathrm{c}}$ \\
\hline
\end{tabular}

${ }^{a}$ the species name given in the source is maintained

${ }^{\mathrm{b}}$ identification based only in morphology

${ }^{c}$ measured from figures in the source

${ }^{\mathrm{e}}$ note that the same strain has been analyzed in two studies

${ }^{\mathrm{f}}$ traits not measured independently for the two populations (Kuwait, Jordan)

${ }^{\mathrm{g}}$ strains with identical rDNA sequences

This article is protected by copyright. All rights reserved. 
Table 2. Uncorrected genetic distance ( $p$ ) values (substitutions per site) among Fukuyoa strains in the ITS-rDNA region (ITS1-5.8S-ITS2). Sequence accession numbers: IR4G, AB765925 F. cf. yasumotoi; GYASU, GU968498 F. yasumotoi; NOAA8, GU968494 F. ruetzleri; Dn135EHU, LN880855 F. paulensis.

\begin{tabular}{|c|c|c|c|c|}
\hline Strain 1 & Strain 2 & $\begin{array}{l}\text { Pairwise } \\
\text { deletion }\end{array}$ & $\begin{array}{l}\text { Complete } \\
\text { deletion }\end{array}$ & $\begin{array}{l}\text { No } \\
\text { deletion }^{\mathrm{a}}\end{array}$ \\
\hline IR4G (F. cf. yasumotoi) & GYASU & 0.011 & 0.013 & 0.024 \\
\hline IR4G & NOAA8 & 0.031 & 0.025 & 0.050 \\
\hline GYASU $(F \cdot$ yasumotoi $)$ & NOAA8 & 0.040 & 0.033 & 0.063 \\
\hline IR4G & Dn135EHU (F. paulensis) & 0.065 & 0.065 & 0.175 \\
\hline GYASU & Dn135EHU & 0.065 & 0.063 & 0.183 \\
\hline NOAA8 (F. ruetzleri) & Dn135EHU & 0.067 & 0.068 & 0.188 \\
\hline
\end{tabular}

${ }^{\mathrm{a}}$ substitutions, gaps and ambiguous bases considered

Table 3. Principal Ciguatoxin (CTX) congeners, gambierol and gambieric acids analyzed by LC-HRMS with their corresponding molecular ions masses

\begin{tabular}{llll}
\hline CTX congeners & $\begin{array}{l}\text { Chemical } \\
\text { Formula }\end{array}$ & Exact mass & {$[\mathrm{M}+\mathrm{Na}]^{+}$} \\
\hline 49-epiCTX3C & $\mathrm{C}_{57} \mathrm{H}_{82} \mathrm{O}_{16}$ & 1022.5760 & 1045.5660 \\
CTX3C & $\mathrm{C}_{57} \mathrm{H}_{82} \mathrm{O}_{16}$ & 1022.5760 & 1045.5660 \\
51-hydroxyCTX3C & $\mathrm{C}_{57} \mathrm{H}_{82} \mathrm{O}_{17}$ & 1038.5710 & 1061.5610 \\
CTX2 (CTX3 C-52 epimer) & $\mathrm{C}_{57} \mathrm{H}_{82} \mathrm{O}_{18}$ & 1054.5660 & 1077.5560 \\
M-seco-CTX3C & $\mathrm{C}_{57} \mathrm{H}_{84} \mathrm{O}_{17}$ & 1040.5870 & 1063.5770 \\
2-hydroxyCTX3C & $\mathrm{C}_{57} \mathrm{H}_{84} \mathrm{O}_{17}$ & 1040.5870 & 1063.5770 \\
2,3-dihydroxyCTX3C & $\mathrm{C}_{57} \mathrm{H}_{84} \mathrm{O}_{18}$ & 1056.5820 & 1079.5720 \\
CTX4A & $\mathrm{C}_{60} \mathrm{H}_{84} \mathrm{O}_{16}$ & 1060.5920 & 1083.5820 \\
CTX4B & $\mathrm{C}_{60} \mathrm{H}_{84} \mathrm{O}_{16}$ & 1060.5920 & 1083.5820 \\
M-seco-CTX4A-B & $\mathrm{C}_{60} \mathrm{H}_{86} \mathrm{O}_{17}$ & 1078.6030 & 1101.5930 \\
52-epi-54-deoxyCTX1B & $\mathrm{C}_{60} \mathrm{H}_{86} \mathrm{O}_{18}$ & 1094.5980 & 1117.5880 \\
54-deoxyCTX1B = CTX3 & $\mathrm{C}_{60} \mathrm{H}_{86} \mathrm{O}_{18}$ & 1094.5980 & 1117.5880 \\
CTX1B & $\mathrm{C}_{60} \mathrm{H}_{86} \mathrm{O}_{19}$ & 1110.5930 & 1133.5830 \\
P-CTX1 & $\mathrm{C}_{60} \mathrm{H}_{86} \mathrm{O}_{19}$ & 1110.5930 & 1133.5830
\end{tabular}

This article is protected by copyright. All rights reserved. 


\begin{tabular}{llll} 
C-CTX1 & $\mathrm{C}_{62} \mathrm{H}_{92} \mathrm{O}_{19}$ & 1140.6410 & 1163.6310 \\
C-CTX2 (C-CTX1 C-52 epimer) & $\mathrm{C}_{62} \mathrm{H}_{92} \mathrm{O}_{19}$ & 1140.6410 & 1163.6310 \\
Gambierol & $\mathrm{C}_{43} \mathrm{H}_{64} \mathrm{O}_{11}$ & 756.4570 & 779.4470 \\
Gambieric acid A & $\mathrm{C}_{59} \mathrm{H}_{92} \mathrm{O}_{16}$ & 1056.6560 & 1079.6460 \\
Gambieric acid B & $\mathrm{C}_{60} \mathrm{H}_{94} \mathrm{O}_{16}$ & 1070.6720 & 1093.6620 \\
Gambieric acid C & $\mathrm{C}_{65} \mathrm{H}_{100} \mathrm{O}_{19}$ & 1184.7050 & 1207.6950 \\
Gambieric acid D & $\mathrm{C}_{66} \mathrm{H}_{102} \mathrm{O}_{19}$ & 1198.7210 & 1221.7110 \\
\hline
\end{tabular}

${ }^{\mathrm{a}}$ Toxin compounds contained in the standard solution

Table 4. Toxin analyses through LC-HRMS. Results from spectra data and precision of molecular formula assigned (RDB equiv., Relative Double Bonds equivalents).

\begin{tabular}{lllllll}
\hline Source & Toxin compound & $\mathrm{m} / \mathrm{z}$ & $\begin{array}{l}\text { Theo. } \\
\text { Mass }\end{array}$ & $\begin{array}{l}\text { Delta } \\
(\mathrm{ppm})\end{array}$ & $\begin{array}{l}\text { RDB } \\
\text { equiv. }\end{array}$ & Composition \\
\hline Dn135EHU & CTX3 & 1117.58 & 1117.57 & 10.56 & 17.5 & $\mathrm{C}_{60} \mathrm{H}_{86} \mathrm{O}_{18} \mathrm{Na}$ \\
& Gambieric acid A & 1079.64 & 1079.63 & 10.54 & 13.5 & $\mathrm{C}_{59} \mathrm{H}_{92} \mathrm{O}_{16} \mathrm{Na}$ \\
Standard & & & & & & \\
mix solution & CTX4A, CTX4B & 1083.57 & 1083.57 & 7.84 & 18.5 & $\mathrm{C}_{60} \mathrm{H}_{84} \mathrm{O}_{16} \mathrm{Na}$ \\
& CTX3C & 1045.56 & 1045.55 & 8.19 & 16.5 & $\mathrm{C}_{57} \mathrm{H}_{82} \mathrm{O}_{16} \mathrm{Na}$ \\
& CTX3, 52-epi-54-deoxyCTX1B & 1117.58 & 1117.57 & 8.06 & 17.5 & $\mathrm{C}_{60} \mathrm{H}_{86} \mathrm{O}_{18} \mathrm{Na}$ \\
\hline
\end{tabular}
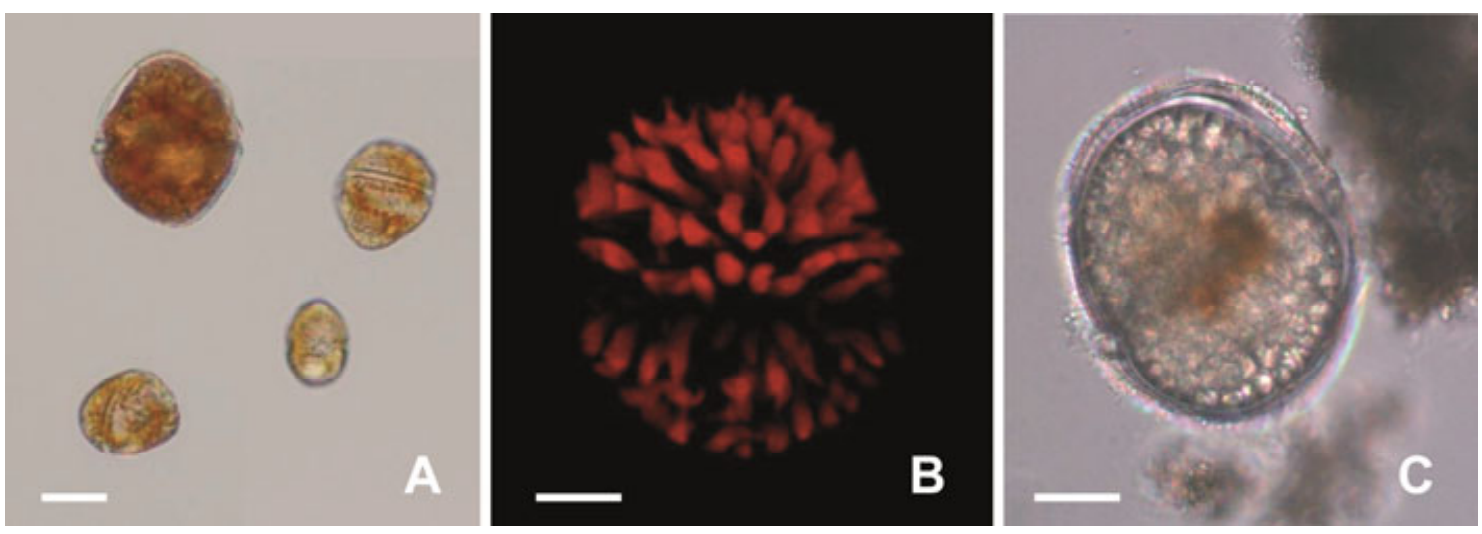

This article is protected by copyright. All rights reserved. 

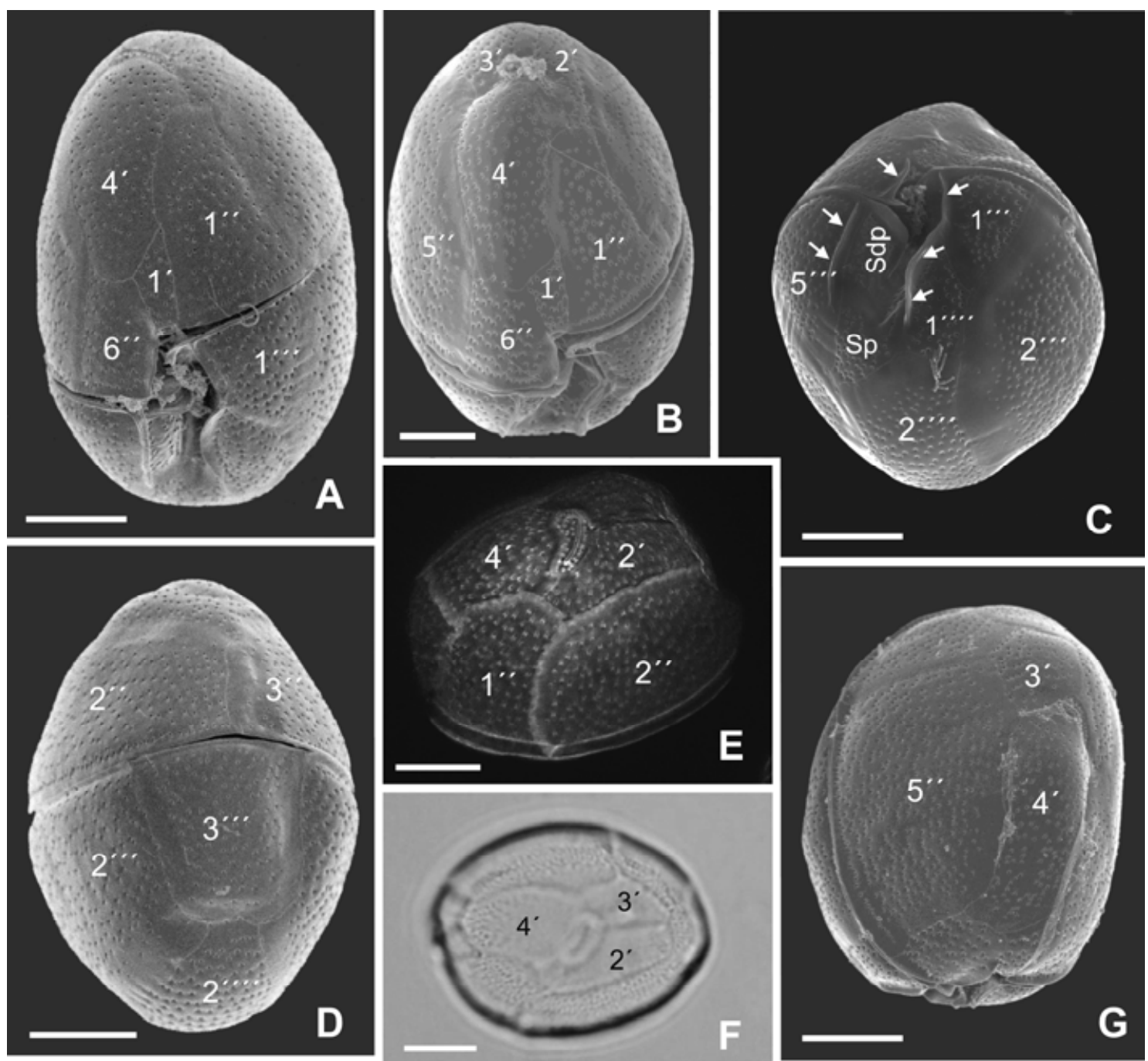

C
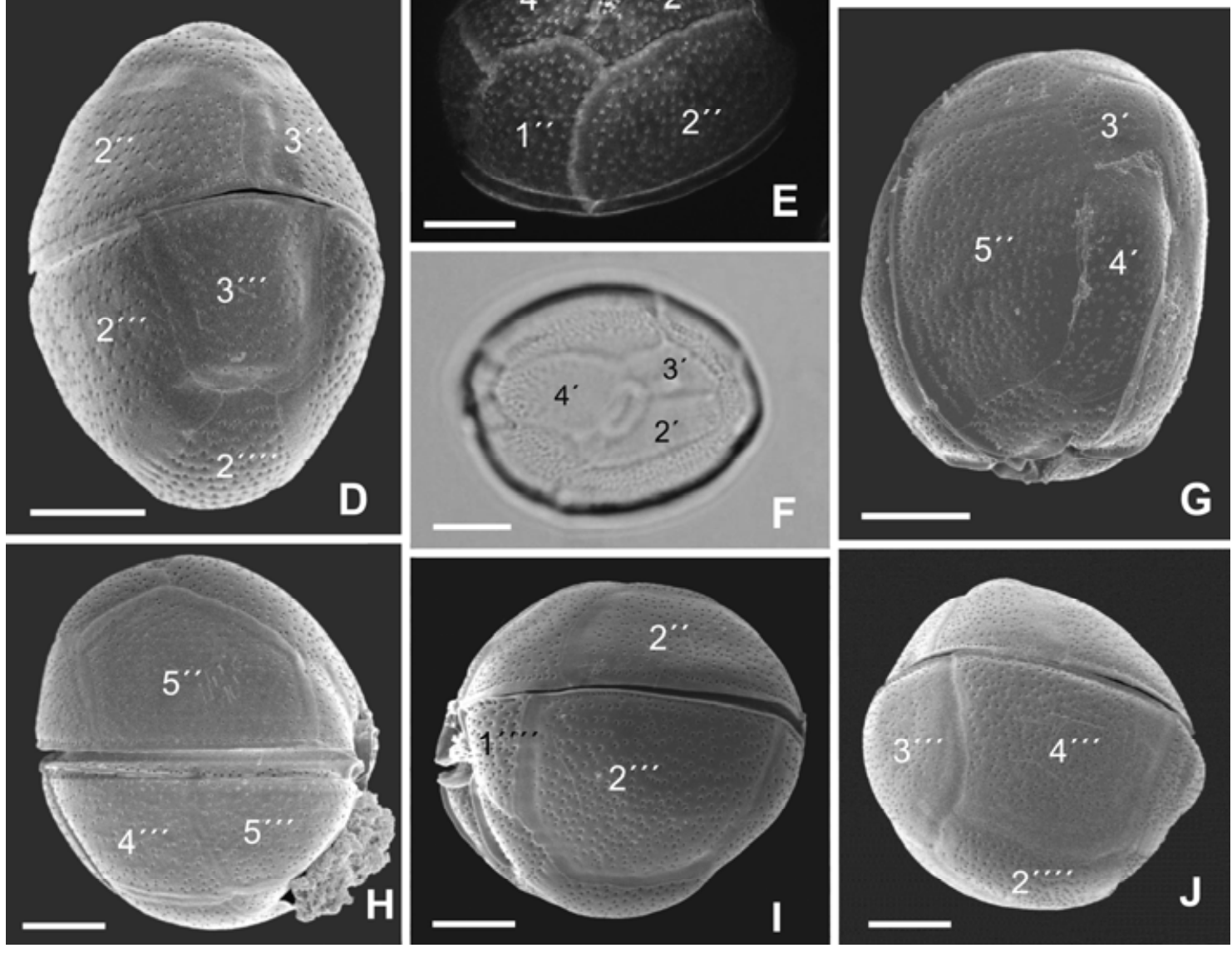

This article is protected by copyright. All rights reserved. 


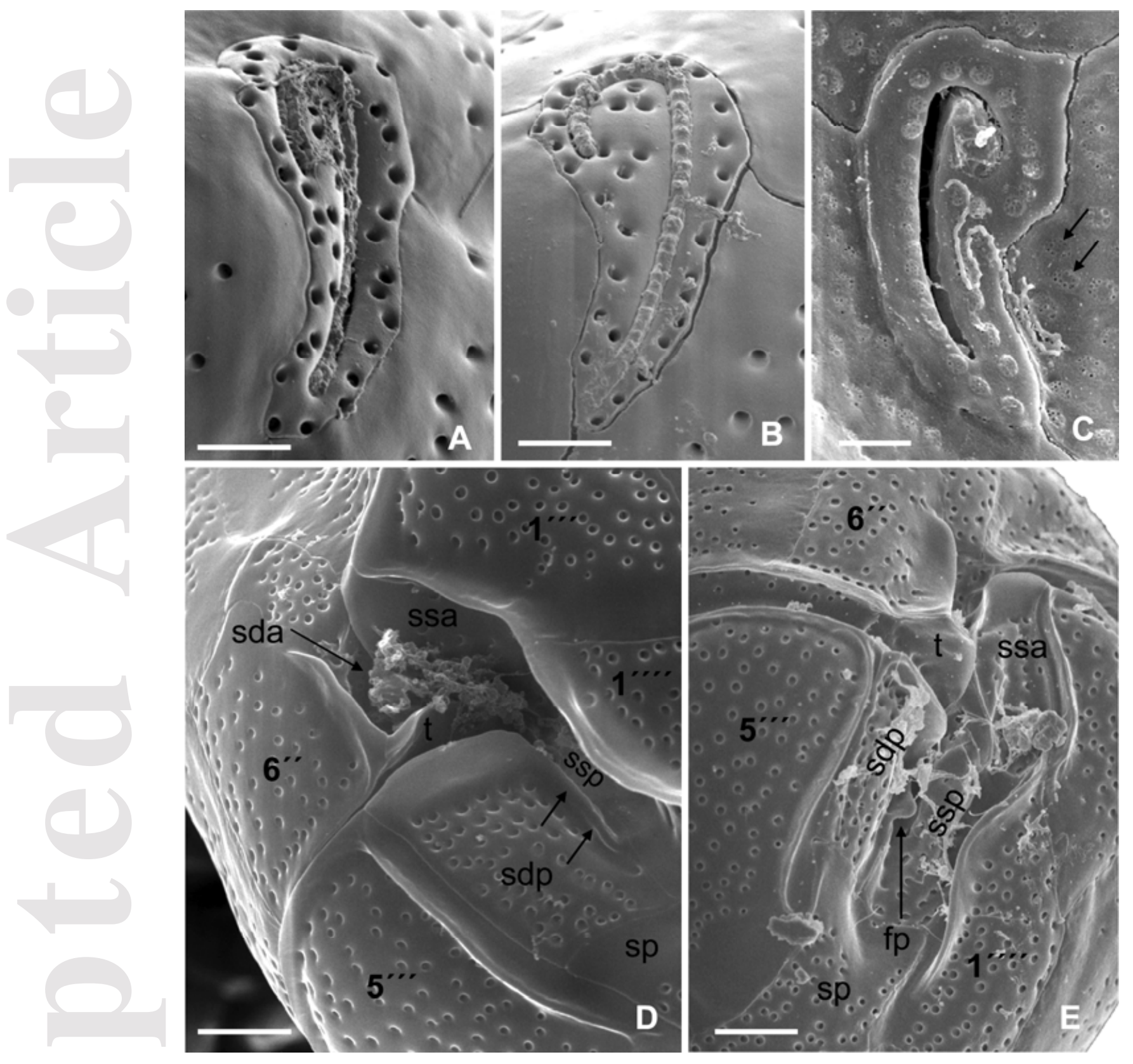

This article is protected by copyright. All rights reserved. 

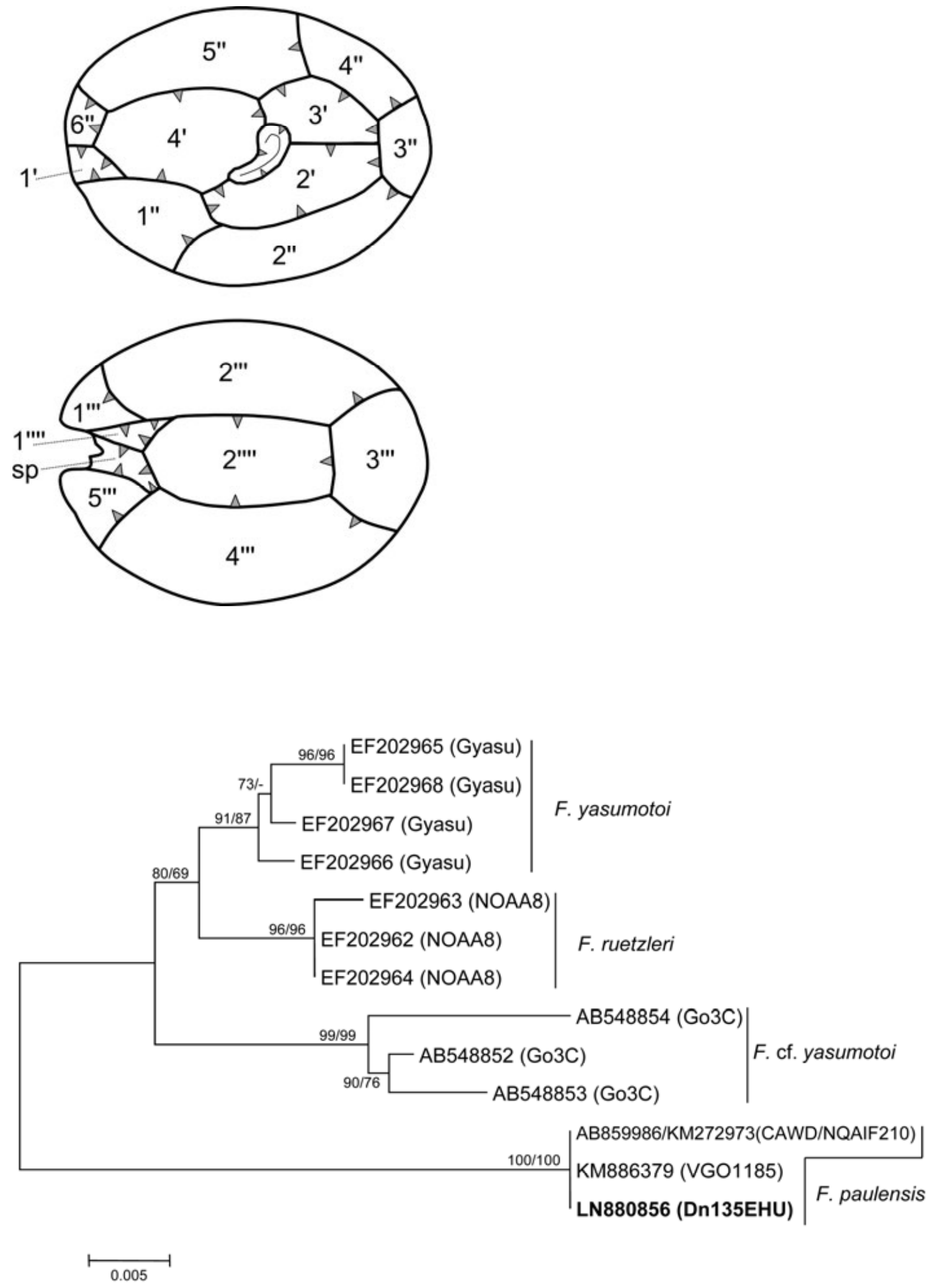

This article is protected by copyright. All rights reserved. 

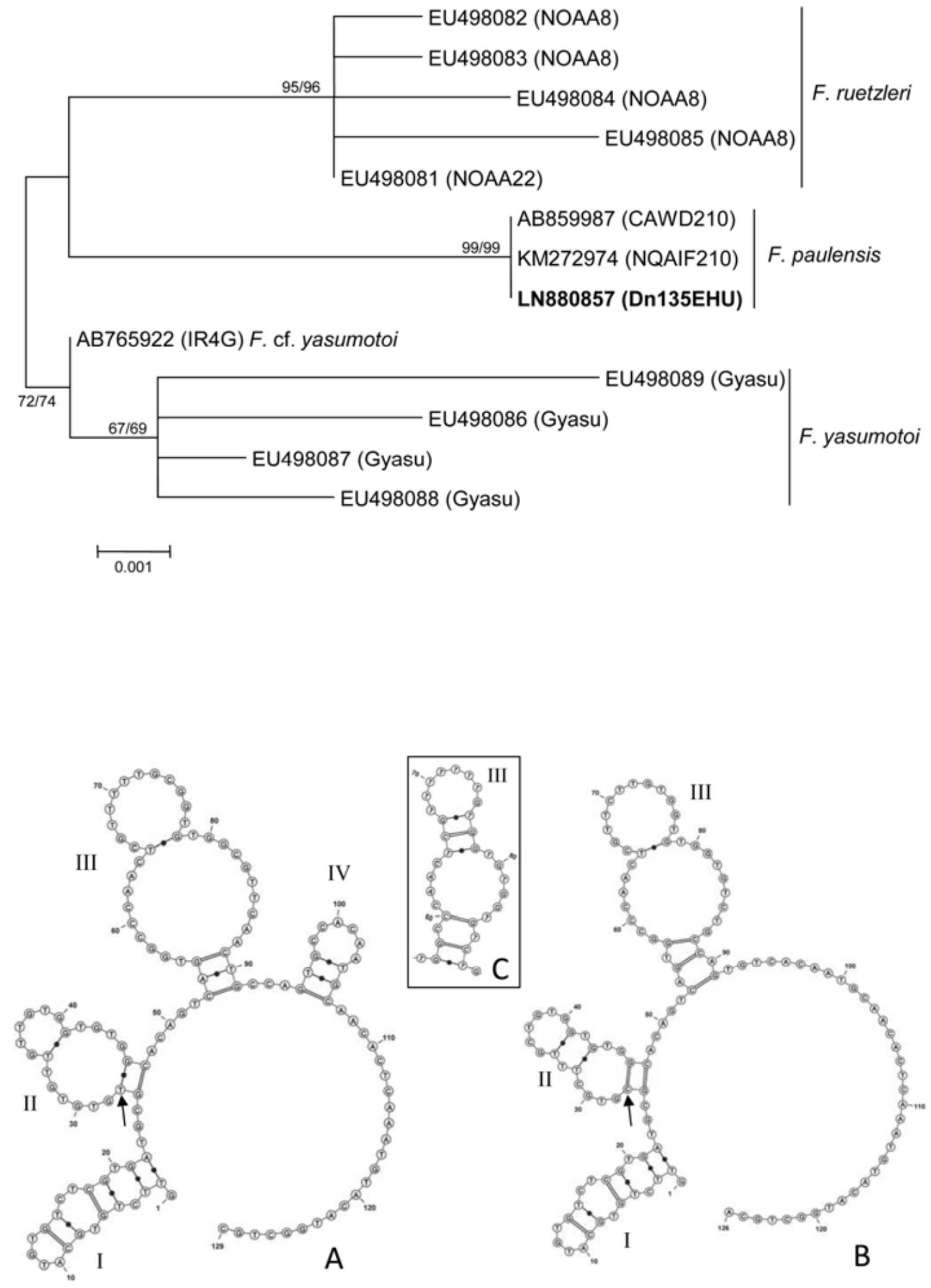

This article is protected by copyright. All rights reserved. 

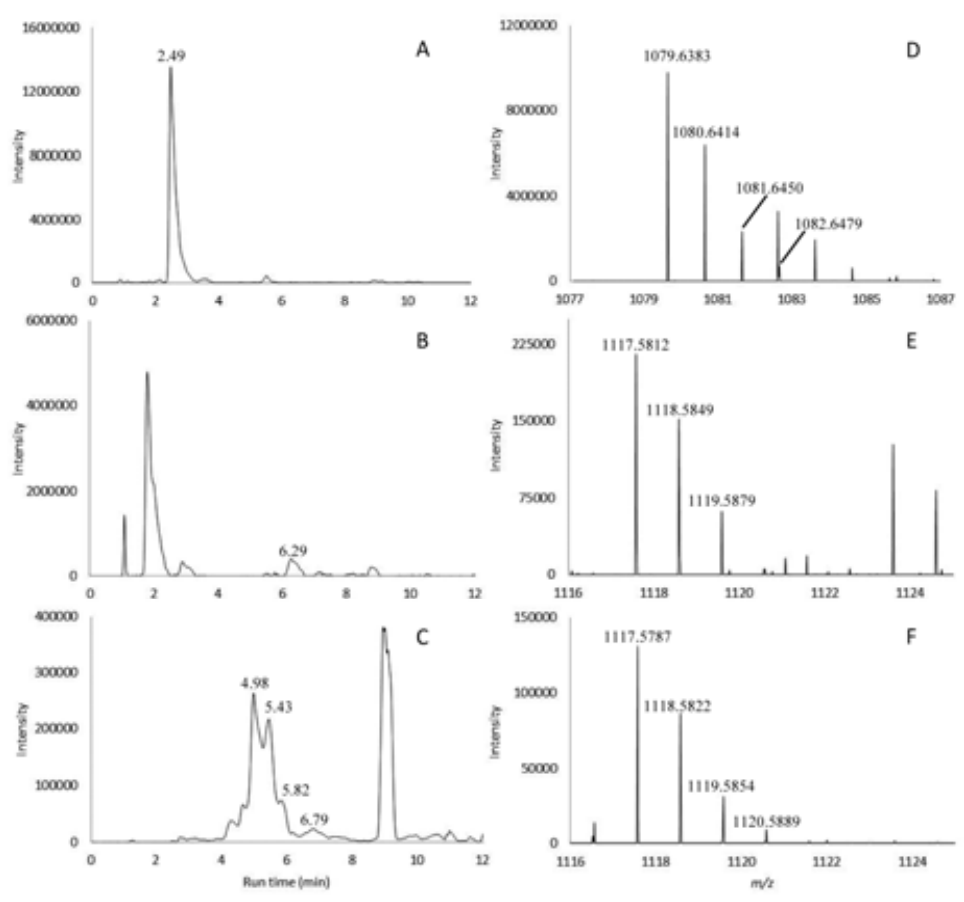

This article is protected by copyright. All rights reserved. 